\title{
Assessing the Vulnerability of Military Installations in the Coterminous United States to Potential Biome Shifts Resulting from Rapid Climate Change
}

\author{
Richard H. Odom ${ }^{1} \cdot$ W. Mark Ford ${ }^{2}$
}

Received: 18 February 2020 / Accepted: 2 July 2020 / Published online: 15 July 2020

(c) This is a U.S. Government work and not under copyright protection in the U.S.; foreign copyright protection may apply 2020

\begin{abstract}
Climate-change impacts to Department of Defense (DoD) installations will challenge military mission and natural resource stewardship efforts by increasing vulnerability to flooding, drought, altered fire regimes, and invasive species. We developed biome classifications based on current climate for the coterminous United States using the Holdridge Life Zone system to assess potential change on DoD lands. We validated classifications using comparisons to existing ecoregional classifications, the distribution of major forest types, and tree species in eastern North America. We projected future life zones for mid- and latecentury time periods under three greenhouse gas emission scenarios (low-B1, moderate-A1B, and high-A2) using an ensemble of global climate models. To assess installation vulnerability $(n=529)$, we analyzed biome shifts using spatial cluster analysis to characterize interregional variation, and identified representative installations for subsequent landscape-level analyses. Although mean annual temperatures are expected to increase, installations located in the Northeast, Lake States, and western Great Plains are likely to experience the largest proportional increases in temperature. Accordingly, forest and grassland communities at these installations managed to support a wide range of training, and environmental objectives may be adversely affected by altered disturbance regimes, heat, and moisture stress. However, precipitation is projected to increase in the Northeast and Lake States mitigating some effects of increased temperatures on biological communities. Given the uncertain response to climate change in different ecoregions, additional environmental and stewardship attributes are needed within a decision-support framework to understand vulnerabilities and provide appropriate responses.
\end{abstract}

Keywords Climate change $\cdot$ Forests $\cdot$ Holdridge life zones $\cdot$ Military installations $\cdot$ North America

\section{Introduction}

Scientific evidence continues to mount that the recent period of climatic warming is exceptional when compared with temperature fluctuations over the past 150 years, especially at higher latitudes (IPCC 2014). Arctic sea ice appears to be shrinking at an unprecedented rate, and mean global sea levels continue to rise, trends linked to the continued

W. Mark Ford

wmford@vt.edu

1 Geospatial and Environmental Analysis Program, Virginia Polytechnic Institute and State University, Blacksburg, VA 24061, USA

2 U.S. Geological Survey, Virginia Cooperative Fish and Wildlife Research Unit, Blacksburg, VA 24061, USA increase in carbon dioxide $\left(\mathrm{CO}_{2}\right)$ and other greenhouse gases in the Earth's atmosphere (Hinzman et al. 2005; Notz and Stroeve 2016). Mean global air and sea temperatures also continue to rise, and most current general circulation or global climate models (GCMs) project these trends to continue over the next century under most emission scenarios (IPCC 2014). A wide range of potential impacts on terrestrial, aquatic, and marine ecosystems throughout the world have been documented, and many more postulated if the current rate of warming continues as projected (Walther et al. 2002; Parmesan and Yohe 2003; Menzel et al. 2006; Botkin et al. 2007; Post et al. 2009; Balmaseda et al. 2013; Moritz and Agudo 2013; IPCC 2014). Bergengren et al. (2011) estimate that as much as $37 \%$ of the Earth's terrestrial ecosystems could experience biome-level changes under the most severe warming scenarios.

In the United States (US), numerous studies over the past decade have also outlined the potential impacts of global 
warming on forest ecosystems, including general declines in growth and productivity (Potter et al. 2012), increased likelihood of damage from insect pests and pathogens (Lovett et al. 2006; Dukes et al. 2009), significant shifts in tree species abundance and ranges (Iverson et al. 2008; Dale et al. 2010; Pucko et al. 2011), negative impacts to life cycles and distributions of fauna (Rodenhouse et al. 2008, 2009) and changes to biogeochemical and hydrologic cycles (Hayhoe et al. 2007; Campbell et al. 2009). Many of these potential impacts are of concern to natural resource managers at Department of Defense (DoD) installations that are responsible for managing large areas to support sustainable range management and training activities while also supporting natural resource stewardship activities. Similar to other federal land managers in the US, resource professionals on DoD installations must comply with requirements of the Clean Water Act, Endangered Species Act, National Environmental Policy Act, the Sikes Act, and other federal environmental legislation, as well as state and local environmental regulations.

Accordingly, DoD land managers could use guidance on how rapid climate change could affect resources in both the short- and long term. Although there is agreement among climate scientists on the general trend in atmospheric warming during the 20th century and projections for $\mathrm{CO}_{2}$-induced temperature increases, there remains considerable uncertainty about how warmer and/or changed climates will impact natural ecosystems at regional (subcontinental) and larger scales (Clark et al. 2001; Millar et al. 2007; Herr et al. 2016; Luce et al. 2016). A major driver of uncertainty is disagreement among GCMs in predictions of future precipitation patterns. As mean annual temperature (MAT) increases, evapotranspiration is expected to increase in many areas of the world (Seneviratne et al. 2006; Bonan 2008; Jung et al. 2010), but if precipitation also increases, the effects of higher temperatures could be mitigated to some degree. For eastern North America, most models predict a $0-10 \%$ increase in precipitation by the latter part of the century (IPCC 2014). However, some models indicate a $0-10 \%$ reduction in precipitation for the southern tier states in the US, and overall, precipitation predictions from current GCMs are within the range of natural climatic variability for much of the eastern half of the country (IPCC 2014). Further, Deser et al. (2012) showed that significant regional variations in both temperature and precipitation projections can occur even within a single GCM when natural climatic variation is considered. Using 40 simulations based on the National Center for Atmospheric Research, Community Climate System Model (CCSM3) with identical climate forcings for North America, Deser et al. (2012) concluded that consistent prediction of similar climate trends (similar sign and magnitude) was only achievable for a few years beyond the limits of observed conditions. Over the next $50+$ years, their results indicated that all of the 40 ensemble projections were "plausible outcomes", and that natural variation in temperature and precipitation patterns contributed significantly to model uncertainty. Fangxing et al. (2013) highlighted that both GCMs and downscaled climate models exhibit significant biases in future predictions of temperature and precipitation patterns at a regional scale, finding no statistically significant trends in precipitation for the northeastern US for end-of-century projections under relatively high $\mathrm{CO}_{2}$ emission scenarios. Hall (2014) suggested that downscaling of GCM outputs might be appropriate in areas with relatively homogeneous regional climates (e.g., mid-continent regions with little topographic relief), but might produce unreliable estimates of future climatic conditions in regions with complex topography or contrasting land cover (e.g., strong regional effects on temperature and precipitation from the Great Lakes).

Responses to rapid global warming are likely to be highly regionalized, and it is unclear if predicting specific local impacts (e.g., increase or decrease in wetland areas, changes in endangered species' populations/distribution, or likelihood of tree species becoming regionally extirpated) at various DoD installations in widely differing bioclimatic regions is appropriate using current global and regional climate models (Araujo et al. 2005; Guisan and Thuiller 2005). Pielke et al. (2007) suggested that a vulnerability or risk-assessment approach might provide a more comprehensive framework for examining the many potential impacts of rapid global warming on ecological systems. Presently, factors, such as patterns and trends in land use, human population density, availability of required habitat components, and even sociopolitical processes, can have far more pervasive effects on species' distribution and alteration of ecological processes than climate-especially at local geographic scales and over relatively short time periods (Hansen et al. 2001; Bonan 2008; Hof et al. 2011). Therefore, understanding how potential changes in broad temperature and moisture patterns might affect major biomes and their constituent ecosystem services is a critical starting point for developing a comprehensive vulnerability index at an ecoregion scale for the DoD (ERDC 2010). Given the level of uncertainty in projections of future temperature and precipitation patterns associated with current global and regional climate models and the expected differential response of ecosystems in different biogeographic settings, we sought to examine the relative vulnerability of military installations to potential biome shifts as opposed to attempting to quantify specific resource impacts.

\section{Methods}

\section{Data Acquisition and Processing}

Our response study area consisted of 596 DoD installations located in the coterminous US (see Appendix, Table 3 for 
the list of installations) that, in addition to major installations where large numbers of troops are housed and trained, included training ranges, munition-storage sites (arsenals), historical sites, National Guard training areas and other miscellaneous locations managed by the DoD. To model potential biome shifts, we applied the Holdridge life zone system (Holdridge 1947, 1965) to the coterminous US and projected over time using climatic outputs from GCMs. The Holdridge system incorporates MAT, mean annual precipitation (MAP), and potential evapotranspiration (PEVT) to define major life zones or biomes. Developed primarily through research in Central America and the Caribbean, this model has been applied in many areas of the world, including North America (Lugo et al. 1999), Australia (Jia et al. 2012), and globally (Emanuel et al. 1985; Olson et al. 2001; Sisneros et al. 2011). Although not designed to be as detailed as more recently developed ecological classifications used in the US (e.g., Cleland et al. 1997; Comer et al. 2003; Omernik and Griffith 2014), the Holdridge system relies directly on simple climatic variables modeled by all GCMs, and in many ways, avoids the complex geologic, edaphic, and floristic components used by other classifications that are difficult to relate objectively to output from GCMs (Lugo et al. 1999). Moreover, the coarse resolution of the Holdridge system is consistent with the spatial, temporal, and predictive limitations of current climate models, and provides a more suitable framework for analyzing small-scale (large-area) phenomena, such as biome shifts or changes in the geographic range of a species. For the purposes of our project, the Holdridge system provided a means to analyze current and projected climate regimes for military installations in the US that were very climatecentric and relatable in a natural resource management context. We graphically represented MAT and precipitation values within the context of the Holdridge life zone system to better understand how installations were distributed across life zone classes, and to begin developing bioclimatic groupings for subsequent analyses.

To provide input for Holdrige life zone shifts, we downloaded climate data (MAT and MAP) in ASCII raster format covering the coterminous US from the ClimateWizard website (Girvetz et al. 2009; http://www.climatewiza rd.org) for three time periods (current, mid-21st century, and late-21st century) and three future emission scenarios. Current conditions comprised monthly temperature and precipitation data collected at $\sim 8000$ observation points from 1895 to 1997 (Gibson et al. 2002), and we modeled them as a 4-km-resolution grid using climatologically aided interpolation (Parameter-elevation Relationships on Independent Slopes Model, PRISM, Daly et al. 1994, 2008). The PRISM model incorporates geographic and physiographic factors to correct for orographic effects on temperature and precipitation in mountainous and coastal regions (Daly et al. 2008). The ClimateWizard tool utilizes PRISM data from 1951 to 2006 as the basis for the "Historical $4 \mathrm{~km}$ Lower 48 " dataset because observational data from the latter part of the 20th century were more abundant (larger number of weather stations) and we considered them more reliable. We modeled MAT and MAP for 2055 and 2085 using average values from an ensemble of 16 GCMs (Girvetz et al. 2009; see Appendix, Table 3) because climate-change studies have shown that using averaged values from multiple models produces more reliable estimates of climatic means than any single GCM (Gleckler et al. 2008; Pierce et al. 2009). Data available from the ClimateWizard site are based on downscaled global climate projections from the World Climate Research Program's Coupled Model Intercomparison Project phase 3 (CMIP3) multimodel dataset (Maurer et al. 2007; Meehl et al. 2007). The three emission scenarios (Nakicenovic et al. 2000) we used from the ClimateWizard site were B1 (aggressive conservation and alternative energy utilization strategies are adopted early in the century, and $\mathrm{CO}_{2}$ levels decrease by $25 \%$ by 2100 ), A1B (carbon dioxide levels continue to rise until mid-century when conservation and alternative energy utilization strategies begin to reduce emissions to $\sim 25 \%$ above current levels by 2100), and A2 (human populations continue to utilize high levels of fossil fuels over the next century, and $\mathrm{CO}_{2}$ concentrations continue to rise to triple the current concentration by 2100). These scenarios are projected to result in mean annual global surface temperature increases of $1.7,2.7$, and $3.5^{\circ} \mathrm{C}$, respectively, above the current mean global surface temperature by the end of the century. Due to the imprecise nature of GCMs, each scenario has a large variance associated with projected temperature increases. For example, for the A2 scenario, projected increases in mean annual global surface temperature by 2100 range from 2.0 to $5.4^{\circ} \mathrm{C}$. Because it was necessary to estimate shifts in boreal life zones across the northern border of the US and into southern Canada, we acquired additional climate data based on a single GCM (the National Center for Atmospheric Research, Parallel Climate Model 1.4 (PCM) available at http://gdo-dcp.ucllnl. org/downscaled_cmip_projections/; Washington et al. 2000) directly from the CMIP3 website. However, we only projected data projected for 2085 under the A2 scenario.

We then imported data into a geographic information system (GIS; ArcGIS 10.2, ESRI, Redlands $\mathrm{CA}^{1}$ ) to derive MAT, MAP, and mean annual PEVT surfaces for 2085 covering the coterminous US and southern Canada. We recognized that life zones in Canada derived from the single PCM dataset could be quite different from those derived from ensemble projections acquired from the

\footnotetext{
1 Any use of trade, firm, or product names is for descriptive purposes only and does not imply endorsement by the US Government.
} 
ClimateWizard site; however, the PCM model has been shown to approximate median results in comparison with other widely used GCMs in terms of projecting mean annual global surface air temperatures at multidecadal scales (AchutaRao et al. 2004). We resampled historical climate data from 4 to $12-\mathrm{km}$ spatial resolution to match the resolution of data for future GCM projections. Our data were projected and georeferenced to the North American Lambert Conformal Conic projection to ensure that subsequent calculations of area and distance were more accurate relative to using nonprojected data. We developed a preliminary cartographic model to guide processing of climate data into maps of Holdridge life zone classes covering the coterminous US. We reclassified continuous raster data downloaded from the ClimateWizard site or derived from CMIP3 data into categories using class thresholds from the Holdridge system. We used the COMBINE function in the ArcGIS Spatial Analyst Toolbox to delineate all unique combinations of categorical data and create raster maps of life zone classes for each date and emission scenario. A majority filter was applied to life zone maps to remove individual outlier pixels.

Once all processing steps were tested and finalized, our final cartographic model was developed using ArcGIS ModelBuilder to automate the classification process (Fig. 1). We visually compared the final life zone maps with distributions of major forest formations and ecological units in the eastern US to assess how well life zones based on historical climate data fit with widely used descriptions of vegetation and ecological systems. Spatial data depicting an updated version of forest formations originally described by Braun (1950) as modified by Dyer (2006) to account for widespread landscape change in the late 19th and early 20th centuries were overlaid on Holdridge life zones in ArcGIS. We acquired province-level data from the National Hierarchical System of Ecological Units (ECOMAP, Cleland et al. 1997) for comparison with life zone maps. ECOMAP incorporates a hierarchical framework for classifying and mapping ecological units from a continental scale $(1: 7,500,000)$ to landscape units applicable to forest management (1:24,000), and has been widely used as the basis for analyzing species distributions, climate change, and other biogeographic studies. The major climate zones in North America are captured at the "Division" level in ECOMAP, but vegetation formations (e.g., boreal forest, prairie, and steppe-shrub) are described at the province level and provided a higher level of geographic detail for relating Holdridge Life Zones to broad biological communities.

\section{Assessing Change}

For the eastern half of the US, we extracted the latitude and longitude of centroids derived from ellipses fitted to each
Holdridge life zone from spatial data layers for all emission scenarios at years 2006, 2055, and 2085 using the Zonal Geometry Tool in ArcGIS 10.2. We then calculated the distance between current and projected life zone centroids and general direction of shifts. We combined life zones with relatively similar climatic conditions and geographic distributions to simplify analyses and interpretation of the results. In addition, life zones in the southern Appalachian Mountains with very small areas $\left(<1000 \mathrm{~km}^{2}\right)$ were not included in tabular summaries. Many of these zones comprised only 1-2 map pixels, and although interesting from an ecological perspective, our confidence in their classification and positional accuracy was low. Similarly, we determined using ellipse centroids to quantify that biome shifts were not useful for much of the western US where the spatial pattern of life zones was highly irregular and fragmented due to topographic variation in mountainous areas. Accordingly, some analytical results were limited to the context of the eastern US. We determined that \% change in mean climatic variables was determined for 529 military installations by comparing climate values from projected data with historical baselines (projected values - historic values)/historic values $\times 100$ ).

Last, we used nonhierarchical, $k$-means cluster analysis to analyze change at DoD installations using \% change in mean annual temperature (CHGMAT), mean annual precipitation (CHGMAP), and mean annual potential evapotranspiration ratio (CHGPEVT) as input variables using cluster groups ranging from 4 to 10 to explore potential regional variation and assist in identifying representative installations at a regional level for additional research. $K$ means clustering is a widely used tool for visually exploring multivariate variation in large datasets where hierarchical relationships are not of interest (Jain 2010). K-means clustering seeks to minimize the variance in groups of similar observations while maximizing the between-group distance. We scaled input variables individually because they were already expressed on a proportional scale. We evaluated differences in groups using bivariate plots of principal component scores resulting from $k$-means analyses, standard boxplots, and a Kruskall-Wallis nonparametric test for differences in group medians (Kruskal and Wallis 1952; Zar 2010). We also compared distributions for CHGMAT, CHGMAP, and CHGPEVT using histograms and evaluation of summary statistics. All statistical analyses were performed in JMP Professional (JMP ${ }^{\oplus}$, Version 11. SAS Institute Inc., Cary, NC, 1989-2007).

\section{Results}

We projected that approximately two-thirds of the country could experience MAT increases in the $12-19 \%$ range, but 


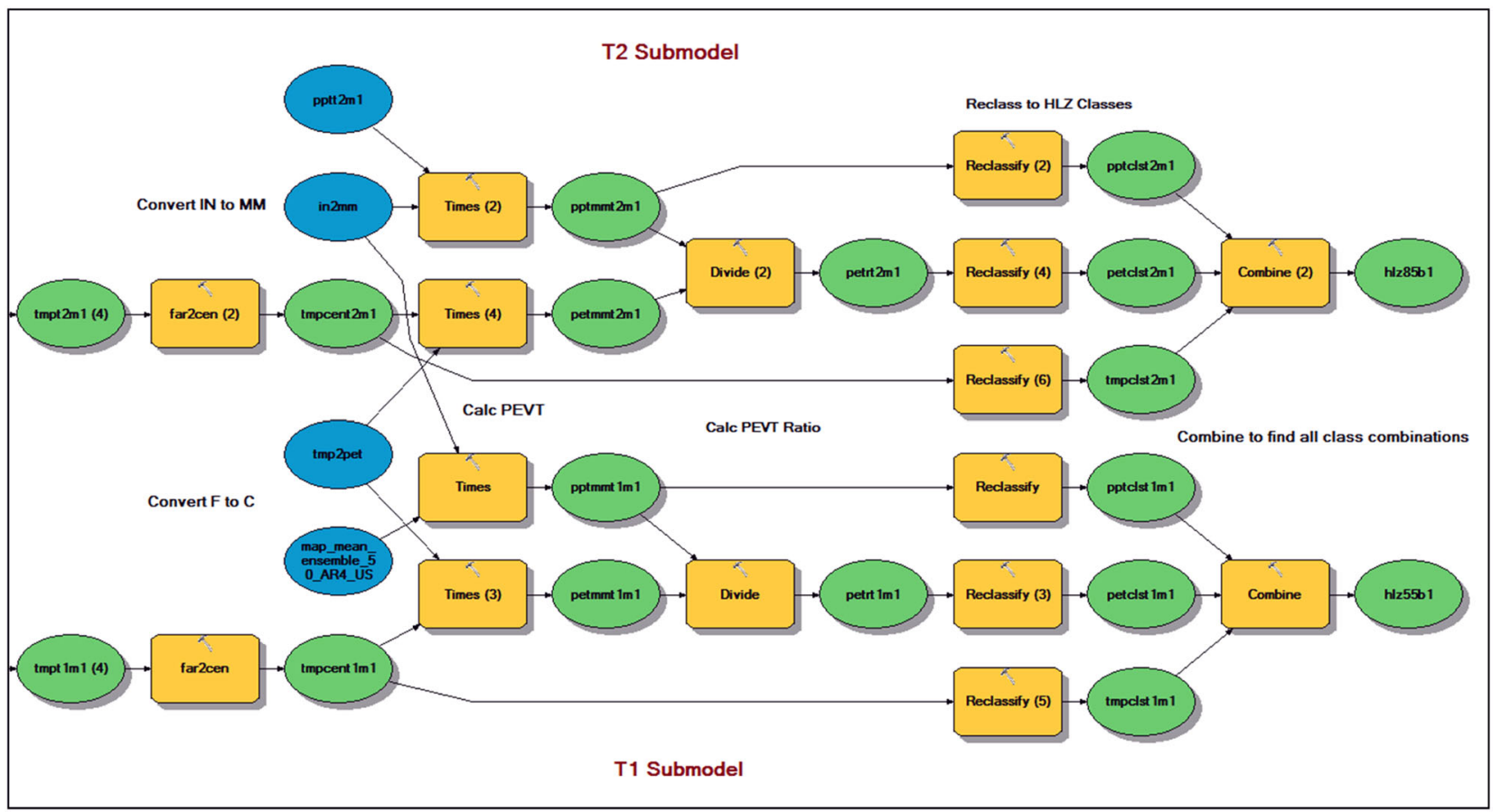

Fig. 1 Cartographic model illustrating the process of developing Holdridge life zone maps from projected climate data based on average values from an ensemble of 16 global climate models (Girvetz et al.
2009). Example shown is for the B1 emission scenario (IPCC 2007) for years 2055 (T1 submodel) and 2085 (T2 submodel). Model created in ArcGIS 10.2.1 ModelBuilder (ESRI 2014) the Intermountain West, northern Great Plains, and northern New England were projected to have increases ranging from 20 to $30 \%$ (Fig. 2a). In contrast, MATs in southern tier states and the West Coast were projected to increase by $10-13 \%$ and the immediate Gulf Coast area by less than $10 \%$ from current conditions by 2085 under the A2 scenario. Projected changes in precipitation were more variable than for temperature with some areas of the country projected to decrease by more than $10 \%$ (southern California, southern Great Plains, and some portions of the desert Southwest) and other areas to increase by a similar amount (northern Great Plains and northeastern US, Fig. 2b). Patterns of projected changes in PEVT were directly related to projected temperature and precipitation patterns, but the relatively large increases in MAT projected for the Rocky Mountain plateau and northern tier states appeared to offset projected increases in precipitation in these areas, resulting in very large increases in PEVT relative to other areas of the country (Fig. 2c).

Classification of climate surfaces using thresholds from the Holdridge life zone system resulted in 65 zones being identified in the coterminous US based on historical climate data (Fig. 3a), and 71, 71, and 68 classes identified for the 2085 B1, A1B, and A2 scenarios, respectively (Fig. 3b, only life zones for the 2085-A2 scenario are shown). The 13 largest life zones, which represent $20 \%$ of the total number, comprised $78 \%$ of the total area. The three largest life zones make up over $37.6 \%$ of the total area (Table 1). Under the
A2 scenario, boreal life zones are projected to be eliminated from the eastern US by 2085, excluding very isolated areas in the highest elevations of the northern Appalachian Mountains. The centers of boreal zones in the northeastern US shift $500-600 \mathrm{~km}$ northward into Canada, and these boreal areas were largely replaced by cool temperate humid and perhumid regimes. Concomitantly, subtropical zones in the southern US increased substantially in the area (>200\%) and expand from their current positions in southern Florida and the Gulf Coast as far north as western Kentucky and southeastern Virginia. By 2085, subhumid and semiarid tropical zones that do not currently exist in the US covered most of the Florida Peninsula and eastern Texas (Figs. 2b, $3 a, b)$. The warm-temperate humid life zone that currently dominates the southeastern US from Texas to Virginia did not change substantially in areal extent (12\% decline from current conditions to 2085-A2), but shifts northward $\sim 600 \mathrm{~km}$ and spans an area from Missouri to southern New England. Under all emission scenarios, most life zones in the eastern US shift northward as expected, given the general zonal nature of MAT in the region. However, a relatively small warm-temperate, subhumid steppe-woodland class (life zone 543) currently located in central Oklahoma, is projected to expand significantly into the Midwest as the climate warms, increasing its areal coverage by over $1400 \%$. The average shift for all life zone centroids in the eastern US by 2085 was $600 \mathrm{~km}$ in a north-northeast direction or $\sim 8 \mathrm{~km}$ per year (Table 2). An overlay of Holdridge life zones 


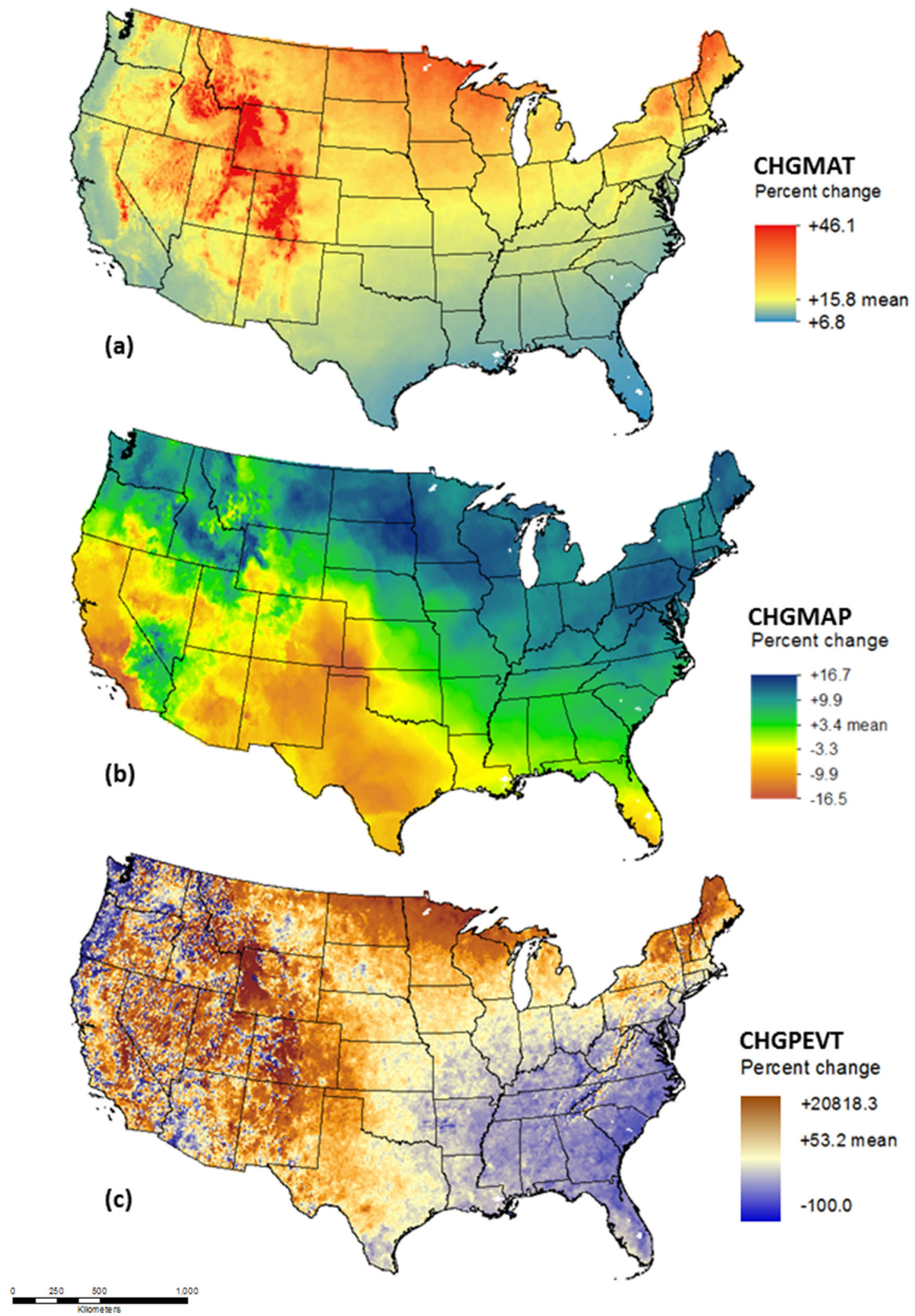

Fig. 2 Percent change in mean annual temperature (CHGMAT; a), mean annual precipitation (CHGMAP; b), and mean annual potential evapotranspiration ratio (CHGEVT; c) from 2006 to 2085 in the coterminous US based on projections from an ensemble of 16 global climate models under a relatively high $\mathrm{CO}_{2}$ emission scenario (A2) 

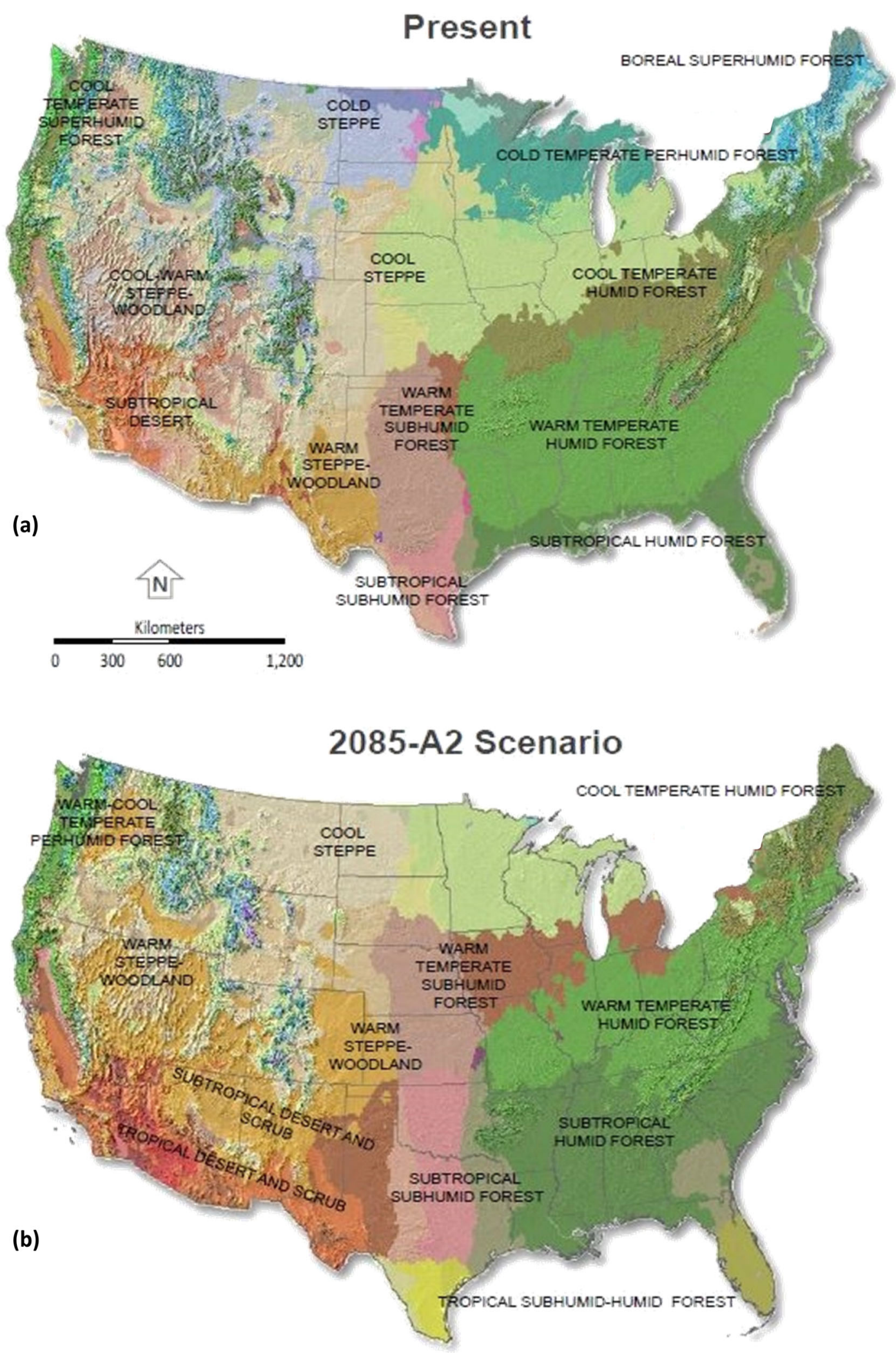

Fig. 3 Maps of Holdridge life zones for the coterminous US based on historical (a) and projected (b) climatic means (all zones are not labeled). Source data from the ClimateWizard tool, http://www.climatewizard.org/ (Girvetz et al. 2009) 
with widely used maps of eastern forest formations and ecological provinces showed high congruence in some regions, but relatively poor correlation in transitional areas between warm-temperate and boreal zones (Figs. 4, 5). Dyer's (2006) eastern hemlock (Tsuga canadensis)-northern hardwood and northern hardwood-red pine (Pinus resinosa) formations closely match boreal life zones with perhumid and humid moisture regimes in the northeast and western Great Lakes regions, respectively. In the southeastern US, the southern mixed and subtropical evergreen forest formations also correspond with warm-temperate humid and subtropical humid life zones. The American beech (Fagus grandifolia)-maple (Acer saccharum), oak (Quercus spp.)-hickory (Carya spp.), and mesophytic formations are distributed across at least two and as many as four life zones, which is not unexpected, given the influences of regional topography (Appalachian and Quachita-Ozark Highlands) and the very broad geographic distribution of the mesophytic forest formation as defined by Dyer (2006).

Distributions of oak-chestnut (Castanea dentata) and mixed mesophytic formations as originally defined by Braun (1950) closely match cool temperate perhumid and humid life zones along the Appalachian Mountains (Fig. 5). However, The Quachita-Ozark Highlands are apparently not sufficient in elevation for their effects on regional climate to be seen at this scale of analysis, and the oak-hickory formation as mapped by Dyer (2006) or Braun (1950) does not correspond well with the distribution of any life zone in the Holdridge system. The influence of the Appalachian Mountains was also evident when comparing life zones with ECOMAP units in the eastern US Ecological units with the " $M$ " designation for mountainous regions (M211 and M221) corresponds well with montane boreal superhumid and cool temperate perhumid life zones in the northern and southern Appalachians. Non-montane boreal life zones correspond with the Laurentian (212) and Northeastern (211) Mixed Forest Provinces in the ECOMAP system, and cool temperate life zones also are reasonably correlated with the Eastern Broadleaf Forest Province (221) and northern portions of the Central Interior Broadleaf Forest Province (223). However, the southern half of the Central Interior Broadleaf Forest Province was classified as warm-temperate humid forest in the Holdridge system, suggesting similarities with climate conditions farther south. Two ECOMAP units covered most of the southeastern US, the subtropical Southern Mixed Forest (231) and Outer Coastal Plain (232) Mixed Forest provinces, both of which fell largely into the Holdridge warmtemperate humid forest life zone. Only the immediate Gulf Coast and Florida Peninsula were classified as subtropical under the Holdridge system, whereas ECOMAP suggests that subtropical conditions will extend northward along the Atlantic Coast to the Delmarva Peninsula. The Holdridge

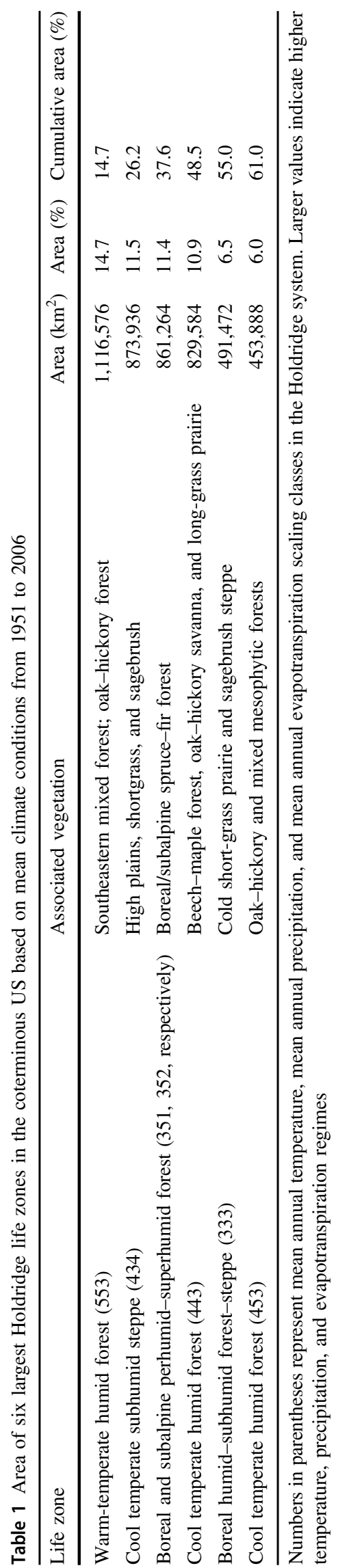




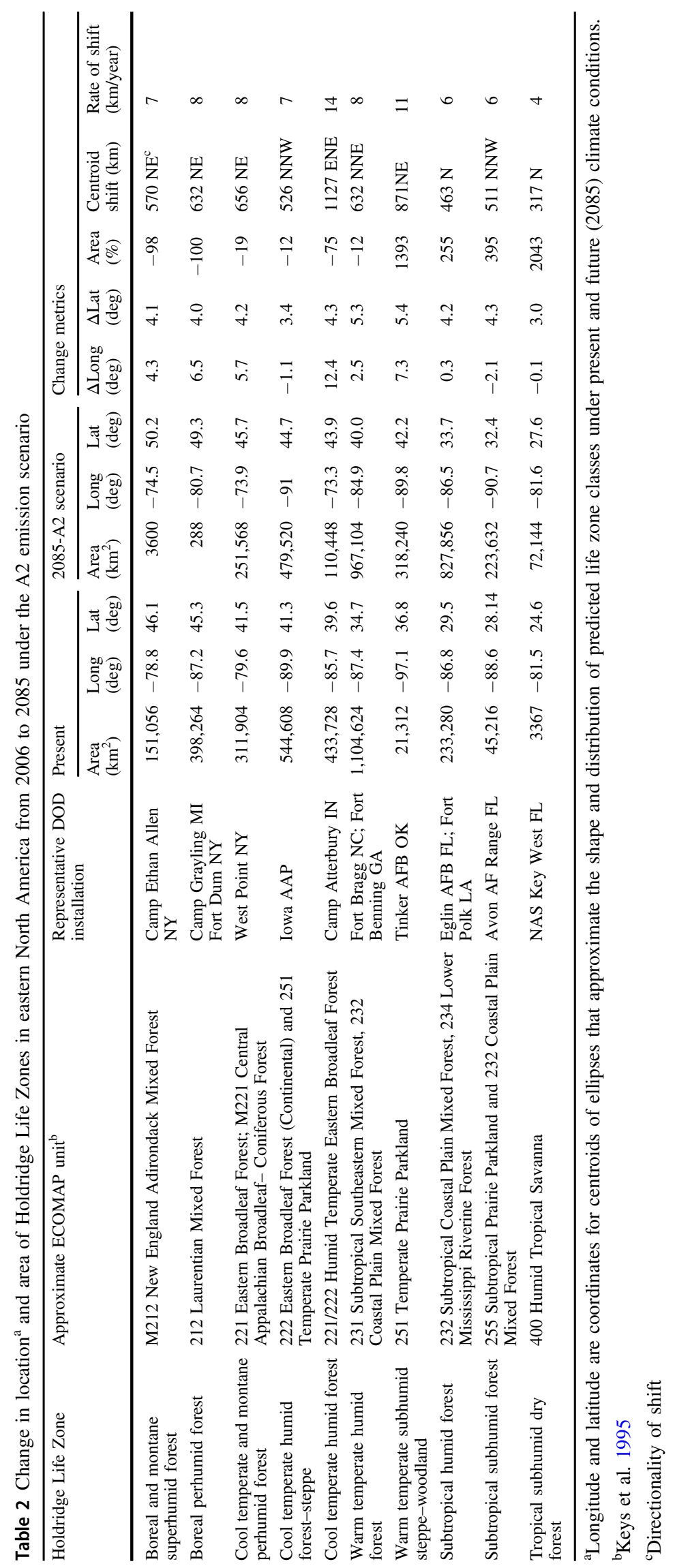


system identifies almost all of Florida as having a distinctly warmer climate than most of the Atlantic Coastal Plain to the north and classifies central Florida as a subtropical dry forest.

Five groups of military installations were identified from cluster analysis of \% change in climate variables from 2006 to 2085 (A2 emission scenario) at 596 locations in the coterminous US (Fig. 6). Examination of biplot graphs and eigenvalues for several $k$-means cluster analyses with the number of predefined groups $(k)$ ranging from 4 to 10 suggested that including $\%$ change in potential evapotranspiration ratio (CHGEVT) added little explanatory value relative to $\%$ change in mean annual temperature (CHGMAT) and mean annual precipitation (CHGMAP). Specifying larger numbers of groups $(k>5)$ tended to create outlier clusters with relatively few observations, and resulted in reassignment of marginal values between groups that did little to elucidate regional patterns. Smaller numbers of groups $(k<4)$ simply grouped large numbers of installations into "clusters" with large geographic ranges and a high degree of within-cluster variability. Four groups appeared to represent overall regional differences with good discrimination, but specifying a fifth group resulted in a cluster of installations in the Interior West being identified (cluster number 2 in Fig. 6) where MAT is projected to increase by almost $16 \%$, and precipitation is projected to decrease by an average of $6 \%$ from 2006 to 2085 under the A2 scenario. Group medians for all five groups were significantly different $(a=0.05, p<0.01)$ for both variables based on the Kruskal-Wallis multiple-comparison test. However, group distributions for CHGMAT and CHGMAP were not all the same, and groups 1 and 5 contained significant outliers for the change in temperature variable (Fig. 6b).

\section{Discussion}

\section{Holdridge Life Zone Changes}

The Holdridge life zone system appeared to capture regional variation in the magnitude and directionality of projected climate changes reasonably well at the relatively coarse scale of our analysis. As expected, major life zones conformed to general temperature and precipitation gradients in the coterminous US that are determined by latitude, prevailing wind direction, major mountain ranges, and proximity to large sources of atmospheric moisture. Lugo et al. (1999) applied the Holdridge life zone system in the coterminous US using similar input data with a 4-km resolution, but only identified 38 life zones, $95 \%$ of which were in the western US. The eastern half of the country comprised almost entirely of two life zones: warmtemperate and cool temperate moist forests (Lugo et al.
1999). The smaller number of life zones in that classification was the result of identifying far fewer temperature classes and slightly fewer precipitation or humidity classes for the majority of the US. The only boreal life zone identified was a small area in the Cascade Mountains in Washington State, and the subtropical zone only covered extreme southern Florida. By comparison, $20 \%$ of the US was classified as boreal and $7 \%$ as subtropical in our analysis, both orders of magnitude larger in areal coverage. The number of precipitation classes was similar. However, Lugo et al. (1999) did not identify any areas in the eastern US with a superhumid precipitation regime, which reduced the number of life zones identified in high rainfall areas in the northern Appalachians. Lugo et al. (1999) relied on an older version of the PRISM dataset, so perhaps it is not surprising that the resulting classifications appear quite different. Much of the difference may also be attributable to the splitting of some temperate life zones in our work into finer classes to more closely match the distribution of widely recognized forest types (e.g., life zone 453, which corresponds roughly to distributions of the central oak-hickory and mixed mesophytic forest types, is a transition zone between the warm-temperate southeastern mixed forest and the cool temperate beech-maple forests that dominate much of the eastern US). Despite differences between the two approaches, Lugo et al. (1999) also concluded that the Holdridge system provided a more objective and climatecentric means of classifying ecoregions in comparison with other ecological classification schemes evaluated in their study. Based on our projections, future distributions of Holdridge life zones in the eastern US may shift as much as $600 \mathrm{~km}$ to the north-northeast by the latter part of the century, resulting in a drastic reduction in the area of boreal and cool temperate life zones and a concomitant increase in the extent of warm-temperate and subtropical zones.

\section{Species Shifts}

The potential shifts in life zones found in this study, both in terms of magnitude and rate of change over time, are largely consistent with the findings of many others for eastern North America that have modeled changes in species' distributions based on projected climate and other environmental data (Overpeck et al. 1991; Iverson et al. 1998, 2008; McKenney et al. 2007, 2011; Woodall et al. 2009, 2010). Iverson et al. (2008) estimated that habitat for 134 tree species in the eastern US would shift from 400 to $800 \mathrm{~km}$ northward by the end of the century under a range of climate-change projections representing "best case" (low $\mathrm{CO}_{2}$-sensitivity model and $\mathrm{B} 1$ emission scenario) and "worst case" (high $\mathrm{CO}_{2}$-sensitivity model and A1F1 scenario) scenarios. Their results indicated that common boreal tree species, such as Balsam fir (Abies 
PRESENT

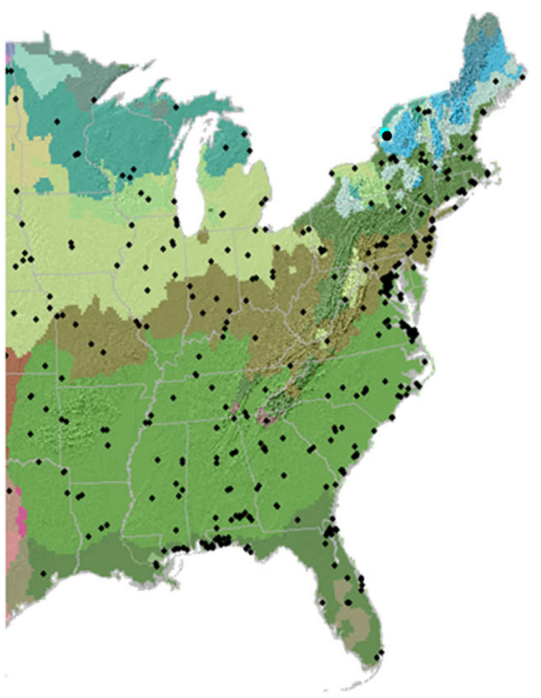

2085-B1

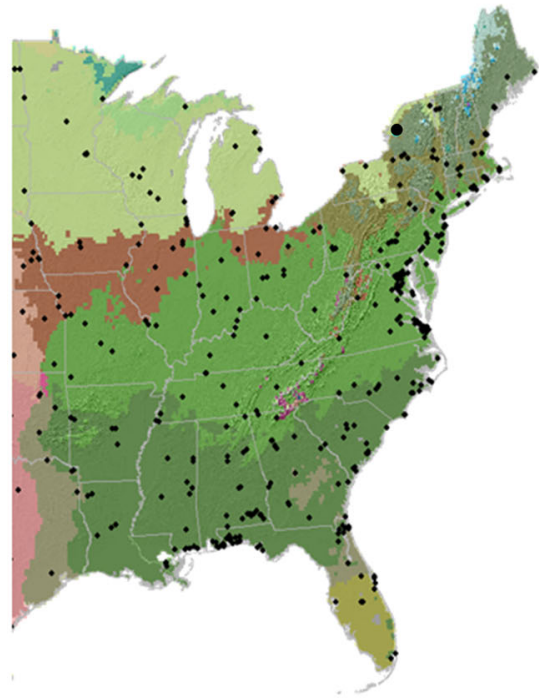

2085-A2

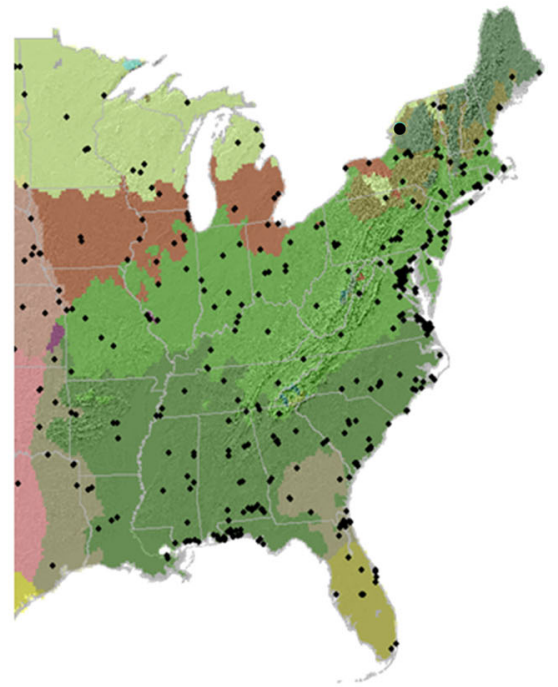

BOREAL HUMID AND PERHUMID FOREST (SPRUCE-FIR, NORTHERN HARDWOODS)

COOL TEMPERATE HUMID FOREST AND WOODLAND (MAPLE-BEECH, OAK-HICKORY WOODLAND)

COOL TEMPERATE HUMID AND PERHUMID FOREST (CENTRAL OAK-HICKORY, MIXED MESOPHYTIC, APPALACHIAN OAK)

WARM TEMPERATE SUBHUMID WOODLAND (OAK-HICKORY WOODLAND AND PRAIRIE)

WARM TEMPERATE HUMID FOREST (OAK-HICKORY-PINE, SOUTHEASTERN MIXED FOREST)

SUBTROPICAL HUMID FOREST (SOUTHEASTERNEVERGREEN, SLASH PINE)

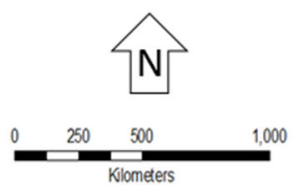

Fig. 4 Holdridge life zones and representative vegetation types for the eastern US based on historical climate conditions (1951-2006) and two future climate projections under different emission scenarios

balsamea), quaking aspen (Populus tremuloides), bigtooth aspen (Populus grandidentatum), red spruce (Picea rubra), black spruce (Picea mariana), yellow birch, and paper birch (Betula papyrifera) would decline in importance relative to more southern species, such as sweetgum (Liquidambar styraciflua), loblolly pine (Pinus taeda), southern red oak (Quercus falcata), winged elm (Ulmus alata), and eastern cottonwood (Populus deltoides). Using a climatic envelope approach to predict change in the ranges of 130 North American tree species, McKenney et al. (2007) also found that species' ranges moved northward an average of $\sim 700 \mathrm{~km}$ (ranging from 330 to $1100 \mathrm{~km}$ ) when modeled using six different GCMs and two emission scenarios (less severe B2 and more severe A2). Because that research covered all of North America instead of just the coterminous US, McKenny et al. (2007) were able to illustrate the potential shifts of boreal species northward into Canada, and therefore did not report these species as losing large expanses of habitat. Instead, they emphasized the potential loss of habitat for many southern tree species due to temperatures increasing beyond their assumed tolerances and their inability to expand ranges northward at a rate that
(low-B1 and high-A2, IPCC 2007). Projections are based on median values derived from an ensemble of 16 GCMs. Black dots are locations of US military installations

would keep pace with projected environmental changes. Many "southern" tree species were predicted to increase in importance in the northeastern US by Prasad et al. (2007) and Iverson et al. (2008). Canham and Thomas (2010) reported that the average local frequency of a tree species (number of plots where a species was present within a particular climate zone) was more informative in defining species-climate relationships than relative abundance of the 24 most common trees in the northeastern US. Their results indicated that several cool temperate species (e.g., red maple (Acer rubrum), American beech, white ash (Fraxinus americana), and black cherry (Prunus serotina)), whose habitats are predicted to decline in other studies, might still be well within their climatic ranges with MATs $3-4^{\circ} \mathrm{C}$ higher than historical averages. Canham and Thomas (2010) also observed that sugar maple, a species predicted to decline substantially under high $\mathrm{CO}_{2}$ emission scenarios in several studies (Iverson and Prasad 1998; Prasad et al. 2007; McKenney et al. 2007; Mohan et al. 2009), maintained relatively high frequencies across a broad range of MAT, suggesting that this widely distributed species may be able to maintain a significant presence in some parts of the 

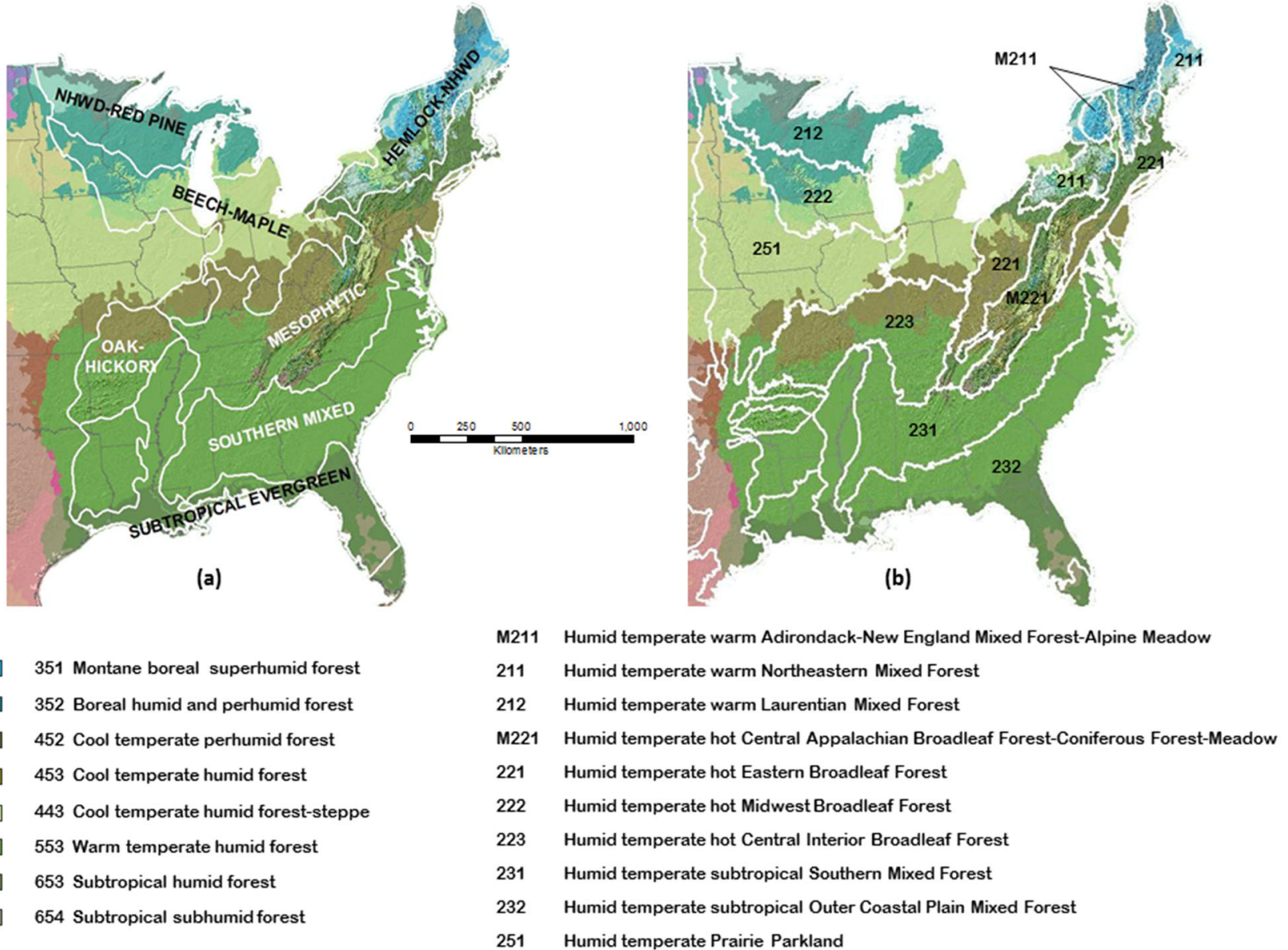

Fig. 5 Comparison of Holdridge life zones (color-shaded areas) developed from historical climate data with major forest formations (a)

classification (Braun 1950; Dyer 2006) shown as white outlines in (a) and province-level data from the Hierarchical Framework of Ecological Units in the United States (Cleland et al. 1997) shown in (b)

eastern US even under more extreme global warming scenarios. For example, sugar maple appears to be able to maintain 20-25\% relative frequency in forests with a mean annual temperature of $11^{\circ} \mathrm{C}$ (Canham and Thomas 2010), which is approximately the MAT projected at Fort Drum in northwestern New York for 2085 under the A2 emission scenario. Based on a recent forest inventory completed at this installation, sugar maple is currently present on $25 \%$ of the inventory plots (Odom and Ford 2020). This is not to suggest that there will be no changes in sugar maple abundance, regeneration, or growth rates under a warmer climate or other species with more northern affinities, but current research based on relatively coarse species distribution models does not provide conclusive evidence on exactly how this and other tree species will be affected in the future by rapid climate change across the broad range of environmental conditions found in the eastern US.

Most predictive species distribution models are based on correlations between the current distribution of tree species as estimated by forest inventory plot data and environmental conditions modeled for the same geographic area
(Odom and Ford 2020). Woodall et al. (2009, 2010) and Zhu et al. (2012) conducted extensive analyses of tree regeneration data from inventories (i.e., distribution of seedlings and saplings) relative to the distribution of adult trees of the same species to ascertain if there was increasing regeneration where the environment is becoming more favorable (northern margin of species ranges in eastern North America) and decreasing regeneration where conditions are becoming less favorable (southern or western margins of retreating climate niches). Their results indicated that the ranges of the majority of tree species in the eastern US (62\% of the 92 species studied) have contracted at both northern and southern margins. Some species (21\%) expanded their ranges to the north and some (16\%) expanded in a southerly direction. This suggests that at a macroscale, there is little empirical evidence of tree species responding to current warming trends in the eastern US by increasing abundance. Still, some tree species have expanded upslope in montane environments, and that these shifts are correlated with local and regional increases in atmospheric temperature (Hamburg and Cogbill 1988; 


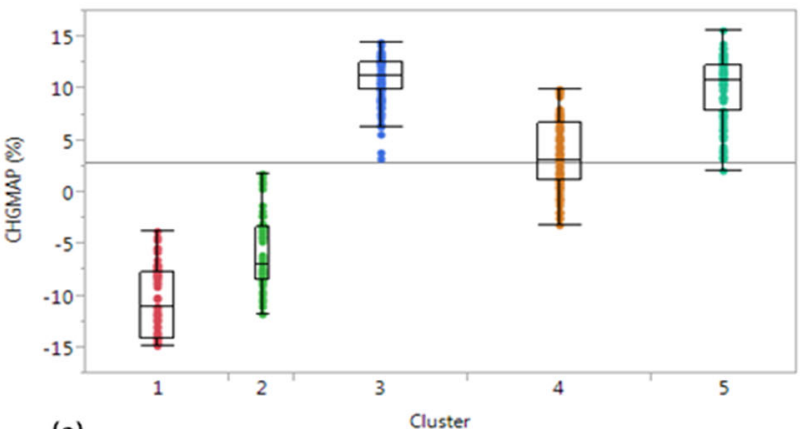

(a)

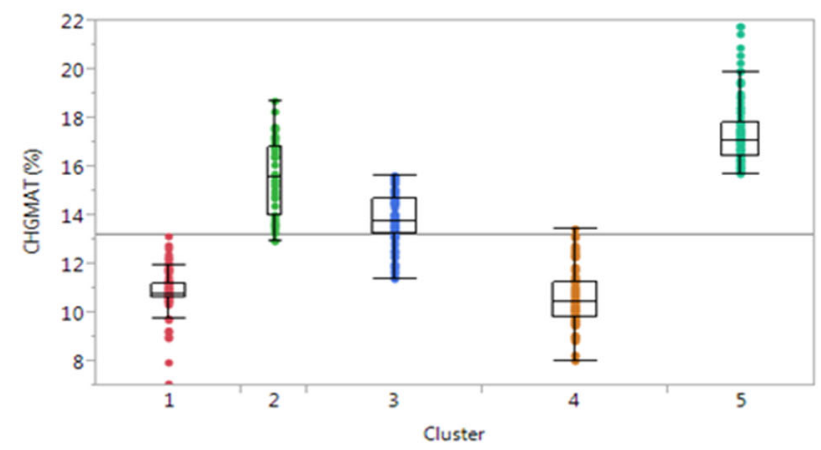

(b)

Fig. 6 Nonspatial cluster analysis $(k=5)$ of percent change in mean annual temperature (CHGMAT) and mean annual precipitation (CHGMAP) projected for 529 military installations in the coterminous US by 2085 under the A2 emission scenario. Group medians in

Beckage et al. 2008; Pucko et al. 2011). However, studies of past changes in species composition in New England have also indicated that disturbance and land use history are strongly associated with the decline of some species (e.g., red spruce) and increased abundance of pioneer species, such as red maple and paper birch in the postColonial era (Foster et al. 1998; Vadeboncoeur et al. 2012). This raises the question of whether the current suite of disturbance-dependent species common across much of southern New England is in equilibrium with historic climatic conditions. If not, this may indicate bias into species distribution models by not accurately representing the full range of climatic conditions under which more shadetolerant and generally mesophytic species thrived prior to extensive human disturbance (Nowacki and Abrams 2015). The climate over the next century may result in a reduction of optimal climatic conditions for boreal tree species, and create more favorable growing conditions for temperate species. For example, this could significantly affect DoD resource management programs throughout the Great Lakes region that currently manage red pine eastern white (Pinus strobus), and Jack pine (Pinus banksiana)), aspen-birch, and mixed hemlock-northern hardwood
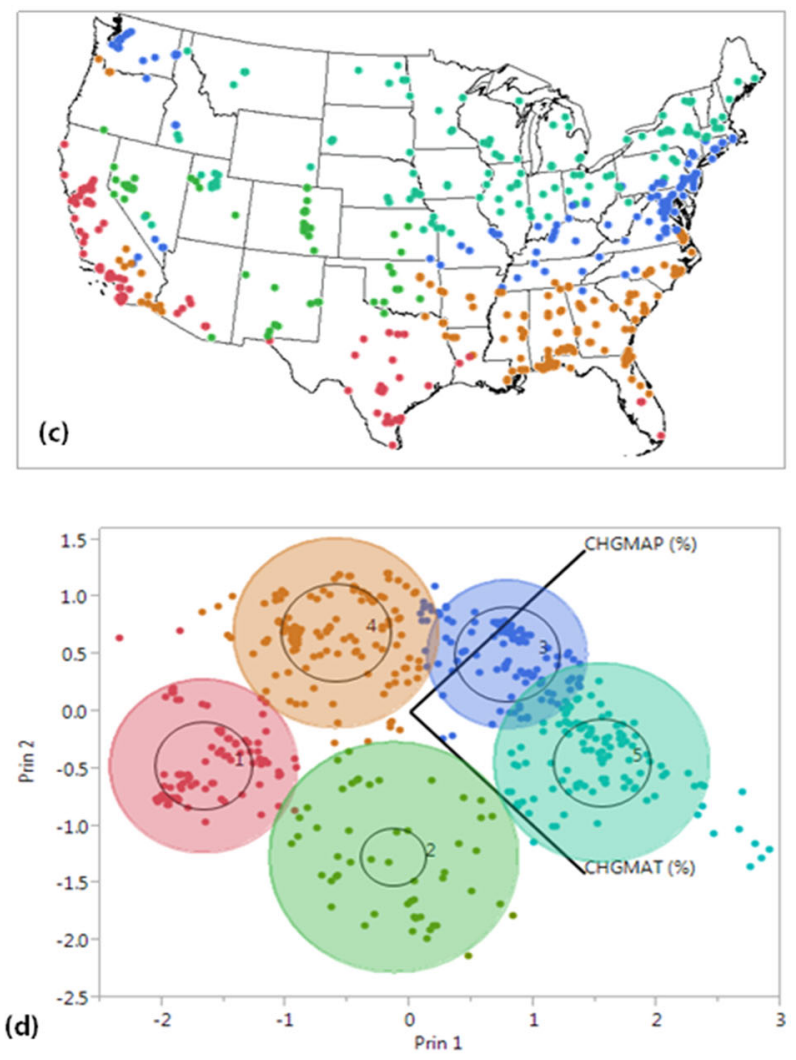

boxplots (a) and (b) are all significantly different $(p<0.01, a=0.05$, Wilcoxon/Kruskal-Wallis nonparametric multiple comparisons). Map (c) illustrates geographic distribution of installation groups, and principal component plot (d) shows distributions in bivariate data space

forests to provide saw logs, pulpwood, fiber for energy production, and wildlife habitat.

A key question is the extent to which other species associated with boreal or cold temperate forests that appear to be less at risk (e.g., sugar and red maple, northern red oak, eastern hemlock, and eastern white pine) or species at the northern edge of their climatic ranges (e.g., white oak (Quercus alba), black cherry, and yellow poplar (Liriodendron tulipifera)) will fill niches vacated by the presumed loss of more cold-tolerant species. Our current understanding of potential tree migration rates $(\sim 1 \mathrm{~km} / \mathrm{year}$ maximum) based on studies of post-Pleistocene forest recovery (Overpeck et al. 1991; Davis and Shaw 2001) and modern seed dispersal studies (Clark 1998) indicates that tree species in eastern North America will not be able to keep pace with the rate of projected climate change (average $8 \mathrm{~km} / \mathrm{year}$ in this study) over the next century (Loarie et al. 2009; Zhu et al. 2012; Snell and Cowling 2015). This suggests that extant tree species in northern forests with greater tolerance for heat-related stress are more likely to capture sites made available by the decline of boreal species than species with northern-range boundaries hundreds of kilometers to the south, at least in the near term. These 
resulting shifts will require resource managers to maintain an adaptive strategy when planning long-term projects such as bioenergy generation that may rely on fiber from particular mixes of tree species. For example, if regeneration of aspen-birch stands at Fort Drum, New York, becomes more problematic due to a shift in dominance to more temperate early successional species, such red maple or black cherry, this could affect plans for bioenergy production at the installation that are currently based on fast-growing aspen-birch stands managed as a coppice. It may be that intensive aspen-birch production could be maintained on certain soil types and moisture regimes where it may have a competitive advantage over more temperate species, but there may also be biological and operational limitations that preclude this approach.

\section{Stewardship Implications}

Potential changes in species composition driven by rapid climate change also represent challenges for endangered species and game management programs on installations in the northeastern and upper midwestern US forest types. Changes projected in northern Michigan by Duveneck et al. (2014) suggest a potential decline in the area of Jack pine forests under warmer and wetter future climate conditions, which could have negative impacts on endangered Kirtland warbler (Dendroica kirtlandii) populations managed at Camp Grayling Army National Guard facility. Broader impacts could be seen at numerous installations for a variety of neotropical migratory songbirds that rely on boreal forest habitats for summer breeding and foraging activities (Rodenhouse et al. 2008). Ralston and Kirchman (2013) projected significant declines in 15 northeastern songbird species and complete loss of 12 species from montane boreal habitats in New York, Vermont, and New Hampshire by 2080 . There are few military installations located wholly in the boreal forest biome south of Alaska, but several in the northeastern US are on the southern margins of boreal life zones, and are likely to experience significant changes in songbird communities under a rapidly warming climate as habitat for northern species' declines and more southern species increase in importance (Rodenhouse et al. 2008). Similar impacts are expected for important game species, such as ruffed grouse (Bonasa umbellus), that depend heavily on early successional brushy habitats dominated by birch, aspen, and willow (Salix spp.) species. In contrast, species such as wild turkey (Meleagris gallopavo) could increase in abundance, especially on installations in the upper Midwest if mast-producing oak-hickory and oak-savanna habitat types displace northern hardwood communities as implied by projected shifts in Holdridge life zones and snow cover duration lessens (Fig. 5). Other wildlife species of concern for military installations in the northeast region include the endangered Indiana (Myotis sodalis) and northern long-eared (Myotis septentrionalis) bats. Populations of these species have declined drastically over the past decade due to a fungal pathogen (Pseudogymnoascus destructans) that disrupts bat physiology and behavior while hibernating in caves during the winter (Silvis et al. 2016). However, global warming would appear to benefit bat species at the northern margins of their ranges by reducing exposure-related mortality during the winter by shortening hibernation duration and increasing the abundance of tree species associated with oak-hickory and mixed mesophytic forests (e.g., shagbark hickory (Carya ovata) and white oak) that provide good roosting sites during the summer (Menzel et al. 2001; Silvis et al. 2016). Depending on the amount and seasonality of future precipitation events, insect populations that are the primary food source for bats may also increase with earlier spring emergence and warmer temperatures expected for the region (Hayhoe et al. 2007). Loeb and Winters (2013) modeled potential changes in the summer distribution of Indiana bats using three GCMs and two emission scenarios, and found that increased temperature and decreased precipitation projected for the western portion of the range may cause these areas to become unsuitable for summer maternity colonies within 10-20 years. The bulk of the species' summer roosting range would shift eastward to the Appalachian Mountains and northeastern US, potentially increasing management concerns for this species on military installations throughout the region.

The hydrologic and edaphic implications of rapid climate change in the northeastern US are complex and difficult to predict due to uncertainties associated with snow and rainfall projections by different GCMs under different future emission scenarios. Based on the ensemble of models used in this analysis, precipitation is expected to increase by an average of $10 \%$ across the region by 2085 under the A2 emission scenario. This concurs with Hayhoe et al. (2007)'s projected 7-14\% increase in MAP based on an ensemble of nine GCMs and three emission scenarios. Precipitation was projected to increase during the winter months and remains unchanged during the summer. Snow cover was projected to decrease in both extent and duration, but average annual soil moisture was expected to increase slightly under a lowemission scenario (B1) or remain unchanged relative to current conditions under a high-emission scenario (A1F1). Surface runoff could therefore increase during the winter months, and low streamflow and soil moisture levels that typically occur in the late summer are likely to occur earlier in the season as temperature and evapotranspiration increase (Huntington et al. 2009). Reduced snow cover and wetter soil conditions could result in challenging range management situations and increased environmental impacts for installations that operate heavy vehicles during the winter 
months, increasing road maintenance and range rehabilitation costs. Drier soils and fine fuels resulting from higher summer temperatures are likely to increase the risk of wildfires from live-fire exercises, but these conditions may also provide opportunities for the use of prescribed fire on installations that heretofore have had little opportunity to use fire as a management tool due to the prevalence of wetto-moist soil conditions for most of the year. On welldrained, coarse-textured soils, prescribed fire could be used at northern installations to maintain red and Jack pine stands, pine-savanna, and oak-savanna habitat conditions that benefit wildlife. Open-forest conditions are also preferred for many military training exercises.

Relative to the northeastern US, installations in the Southeast should see somewhat less dramatic changes in forest species composition and wildlife habitat due to more modest projected increases in MAT $(10.5 \%)$ and precipitation (3.5\%) across most of the region by 2085 under the A2 emission scenario. However, temperature regimes in much of the region are projected to shift from warm temperate to subtropical, and whereas humid conditions are likely to persist in much of the region, significantly lower precipitation is projected for the southern half of the Florida Peninsula and much of Texas. This could result in severe seasonal moisture deficits and increased likelihood of wildfire that may promote the development of subtropical subhumid oak- and pine-shrub savannas in drier portions of the southeast (Clark et al. 2014). This may be largely beneficial to endangered species management on some DoD lands where humid conditions and wildfire suppression have promoted the development of dense woody shrub thickets that are not optimal habitat for some species (e.g., the Florida scrub jay, Aphelocoma coerulescens, at Avon Park Air Force Range in central Florida (Woolfenden and Fitzpatrick 1984) and the golden-cheeked warbler, Setophaga chrysoparia, at Fort Hood and Camp Bullis in central Texas). However, intensification of subtropical-to-tropical subhumid climates in central Texas could also shift the species composition of some woody shrub communities to favor species that are more typical of ecosystems in western and southern portions of the state (e.g., conversion of mixed oak woodland-grassland habitats comprising live oak $(Q$. virginiana), Ashe's juniper (Juniperus ashei), and mesquite (Prosopis glandulosa) to semiarid communities dominated by creosote bush (Larrea tridendata) or subtropical mesquite-blackbrush (Vachellia rigidula) thorn scrub), which could be detrimental to species of concern such as the black-capped vireo (Vireo atricapilla) (Grzybowski et al. 1994; McFarland et al. 2013).

Pine-dominated communities from Virginia to Texas are in general expected to respond favorably in the coming decades to warming trends, and many pine species have been projected to significantly expand their ranges northward (Iverson and Prasad 1998). However, Clark et al. (2014) and Klos et al. (2009) found that many pine species, including loblolly pine (Pinus taeda), are more sensitive to drought than many southern oak and mesophytic hardwood species, and may exhibit higher mortality on upland sites with increasing frequency or intensity of droughts. In addition, Klos et al. (2009) suggested that forest stands with higher species richness and lower densities had lower mortality and better growth responses under various drought conditions in comparison with monospecific stands. This suggests that loblolly pine plantations throughout the south may be more at risk from regional warming and increased evapotranspiration than mixed species' forests comprising more drought-tolerant species such as longleaf pine (Pinus palustris) and slash pine (P. elliotti), or southern oaks and hickories. Depending on how fire regimes are affected and local edaphic conditions, installations in the southeastern Piedmont between the Appalachian Mountains and Coastal Plain may experience increasing encroachment by mesophytic hardwoods (e.g., red maple, American beech, flowering dogwood (Cornus florida), sweetgum, southern magnolia (Magnolia grandiflora), and holly (Ilex spp.)) in pine stands due to projected increases in temperature and precipitation. A trend toward increasing dominance of mesophytic species has been documented in many eastern forests, although the reason for changes in species composition has been attributed more to the lack of disturbance (primarily anthropogenic fire) rather than increased precipitation related to climate change (Alexander and Arthur 2014; Hanberry et al. 2012; Nowacki and Abrams 2008, 2015). Many southeastern pine-dominated forests are maintained through natural and prescribed fires that kill fire-intolerant hardwoods and reduce competition for pine regeneration from woody shrubs, forbs, and grasses. The higher temperatures and increased evapotranspiration expected under projected climate-change scenarios would appear to support continued use of prescribed fire on military installations throughout the southern US. However, expected increases in precipitation in southeastern states, especially during winter months when many prescribed fires are implemented, may offset temperature increases making burning more difficult and less effective in suppressing hardwood growth. It may be that on certain landscape types (e.g., fine textured soils in pine flatwoods), higher soil, and fine fuel moistures resulting from increased precipitation will reduce the effectiveness of prescribed fire to the point that shade-tolerant woody shrubs and hardwood tree species become more competitive. Shifts from pine to hardwood-dominated systems on many southern installations would have important implications for timber production and management of endangered species such as the red-cockaded woodpecker (Leuconotopicus borealis) that depend on pine-dominated ecosystems with open 
understories. However, sites characterized by coarsetextured soils, such as southeastern Sand Hill communities in the Coastal Plain, may be less affected by increased precipitation, and maintenance of longleaf pine communities using prescribed fire may remain a relatively easy task for land managers at installations, such as Fort Bragg, North Carolina, Fort Jackson, South Carolina, and Fort Benning, Georgia. These installations contain significant areas of Sand Hill communities where local edaphic conditions may help maintain xerophytic communities despite the increasingly humid climate projected for the region. Clark et al. (2014) suggested that significant warming in the southeast under more extreme $\mathrm{CO}_{2}$ emission scenarios could push southern forests on more xeric sites toward subtropical savanna-like vegetation, which could potentially reverse the effects of mesophication and help restore pine and oak savannas on many upland landscapes throughout the region. In effect, increasing temperatures and more arid soil moisture conditions could help restore the physiognomy of many upland forest ecosystems across much of the south that existed prior to widespread conversion to cropland and loblolly pine plantations (i.e., a mosaic of southern hardwoods on mesic sites, mixed pine-hardwood forests, and more open oak-hickory and longleaf pine forest-savanna; Frost 2006).

Based on the ensemble GCM projections used in this analysis, the Northern Plains and western Great Lakes region may experience some of the largest increases in MAT $(>20 \%)$ and MAP (>10\%) of any area in the coterminous US outside of the Rocky Mountains by late century (Fig. 2). This region is characterized by strong north-south and east-west gradients in temperature and precipitation, respectively, and as a result encompasses major ecotones between humid boreal and cool temperate forests in the east and the drier grassland communities to the west. The prairie-woodland ecotone in the central US has shifted spatially with variations in climate and fire frequency throughout the Holocene (Williams et al. 2009), and large increases in PEVT expected with strongly warming temperatures would appear to favor expansion of prairie and warm-temperate woody species over more cold-tolerant boreal tree species (e.g., aspen, birches, and spruce-fir). However, natural fire regimes that historically favored grassland systems by limiting encroachment from woody vegetation no longer exist in much of the region due to wildfire suppression and landscape fragmentation by agricultural ecosystems. Over the past several decades, woody plants have been encroaching on prairie landscapes at the margins of the prairie-woodland ecotone primarily due to the absence of frequent wildfires that once maintained grassland and open-woodland habitats (Radeloff et al. 1999; Briggs et al. 2005; Rogers and Russel 2014). In addition, increased precipitation projected for the region over the next
50-70 years may further shift the competitive advantage toward woody warm-temperate species resulting in expansion of oak (Quercus alba, Q. rubra)-hickory (Carya cordiformis, $C$. ovata) and oak (Q. rubra)-maple (A. saccharrum)-basswood (Tilia americana) communities westward into grassland habitats and northward into areas currently dominated by more boreal tree species. There are relatively few military installations with large land bases in the northern plains, but Army National Guard installations located within prairie-forest ecotones, such as Camp Ripley in central Minnesota and Fort McCoy in Wisconsin, should expect increasing encroachment of woody plant species into grassland habitats with concomitant negative effects on plant and animal species adapted to open landscapes (e.g., the federally endangered Karner blue butterfly (Lycaeides samuelis) at Fort McCoy; Wood et al. 2011). However, both installations appear to be successfully maintaining grassland and open-woodland conditions through a combination of prescribed fire, mechanical removal of woody plants, and herbicide applications (Minnesota Department of Natural Resources and Minnesota Army National Guard 2015; Wood et al. 2011). Increasing precipitation from climate change and lack of frequent wildfires in most of the Upper Midwest will in general promote the establishment and growth of temperate mesophytic woody species, but projected increases in regional temperature regimes will also increase evapotranspiration and likely produce significant soil moisture deficits during the growing season in some years. Maintenance of open oak woodland communities on more xeric sites (e.g., sand plains) should be possible if the relationships between fire frequency, site conditions, and competition can be fully understood and appropriate management prescriptions implemented. Species that depend on open, grass-dominated communities may be more at risk under expected future climate conditions, but increased forest cover and increased woody species diversity resulting from warmer and more humid conditions should be beneficial to many mammals such as forest bats and white-tail deer (Odocoileus virginianus), migratory songbird, and herpetofauna species at these installations. The southern and western portions of the Great Plains present a distinctly different scenario with MATs projected to increase by as much as $15 \%$ and MAP projected to decline by $5-10 \%$ in areas from eastern Colorado to central Texas. Ecosystems in the region are likely to experience abnormally long and intense periods of drought by midcentury that exceeds any that has occurred in the past 1000 years (Cook et al. 2015; Williams et al. 2012), which could shift subhumid, cool temperate shortgrass prairie communities (blue grama (Bouteloua gracilis)-buffalograss (Bouteloua dactyloides)-galleta (Hilaria jamesii)) in the western high plains toward warm-temperate, semiarid grassland (black grama, Bouteloua eriopoda; tobosagrass, 
Pleuraphis mutica) and shrub-steppe communities (e.g., mesquite-creosote bush, pinyon (Pinus edulis)-juniper (Juniperus monosperma)) more typical of regions to the south and southwest. Fort Carson, Colorado and Fort Sill, Oklahoma could see declines in temperate grassland communities and expansion of xeromorphic shrubs and other plants characteristic of more arid biomes, which may in the short term increase cover type and species diversity and potentially improve habitat structure for some species of concern (e.g., golden-cheeked warbler, black-capped vireo, and lesser prairie chicken (Tympanuchus pallidicinctus)) at Fort Sill, all of which prefer or require some woodland-savanna habitat. However, shortgrass prairie communities in the southern Great Plains have declined significantly over the past 100 years due to overgrazing by cattle, conversion to cropland, and urban development. Further reductions in the areal extent or ecological function of extant native grassland and woodland-savanna habitats on these installations are likely to have negative effects on populations of black-tailed prairie dogs (Cynomys ludovicianus) and other small mammals that are important food resources for a number of at-risk predator species (e.g., black-footed ferret Mustela nigripes, swift fox Vulpes velox velox, and ferruginous hawk Buteo regalis). Along the eastern Front Range and foothills of the Rocky Mountains, expected decreases in soil moisture under warmer and drier climate conditions are likely to reverse the expansion of ponderosa pine (Pinus ponderosa) forests into the western Great Plains that has been occurring over the past several decades (Kaye et al. 2010).

Based on our analyses, by the end of the century, pine forests will likely be restricted to sheltered canyons and higher elevations where more mesic conditions may persist. This could have significant consequences for Mexican spotted owl (Strix occidentalis) populations at Fort Carson if development and expansion of woody shrub habitat (e.g., pinyon Pinus-juniper Juniperus spp.) does not occur fast enough or is an inadequate substitute for pine forests that provide better cover and nesting sites. The owl is at the northern limit of its range in southeastern Colorado, and the climatic conditions expected to develop over the next 50-100 years may remain within the environmental tolerances of the species in terms of thermoregulated behaviors such as fecundity and roost selection (Peery et al. 2012). However, it seems likely that spotted owls may be forced to utilize higher elevations as forested habitat becomes less dense and more fragmented at lower elevations.

Given the topographic complexity of the western US, the most significant biome shifts in the interior portions of the region are likely to be driven by changes in temperature and moisture patterns related to altitude. A number of studies have identified upslope shifts in species and forest communities in the Rockies (Elliott 2012) and Sierra Nevada
Mountains (Van Mantgem and Stephenson 2007; Kelly and Goulden 2008) that were attributed to recent warming trends, but downslope movement of tree species has also been reported (Crimmins et al. 2011). Projected changes in montane forest communities due to climate change will likely be more complex than simple upward movement of tree species along elevational gradients. Physiographic and edaphic conditions are highly variable in mountainous areas, and variation in the amount and distribution of snowfall will influence how high elevation species respond to changing climate conditions (Malanson et al. 2007). In this study, projected changes in MATs for the western US by 2085 under the high-emission A2 scenario resulted in almost complete loss of high-elevation life zones (Fig. 7), which is consistent with estimates from other studies (e.g., greater than $97 \%$ loss of subalpine and alpine habitats; Finch 2012). There are relatively few military installations at high elevations in the western US, but semiarid woodland and steppe-shrub communities at lower elevations are also at risk from projected increases in MAT and drought over the next century. Cool temperate, semiarid biomes characterized by big sagebrush (Artemisia tridentata) communities are projected to be displaced northward by 200-300 km and contract in area by 40-69\% (Rehfeldt et al. 2006; Finch 2012). Military ranges located near the southern limits of sagebrush distribution in Nevada and Utah could experience encroachment from more drought-tolerant communities such as desert scrub and pinyon-juniper woodlands that would be detrimental to several species of concern, including the greater sage grouse (Centrocercus urophasianus) and pygmy rabbit (Brachylagus idahoensis) (Blomberg et al. 2012; Finch 2012). The Yakima Training Center in Washington and Mountain Home Air Force Base in Idaho are projected to remain at least marginally in a cool temperate, steppe-shrub life zone and could become focal points for conservation of sagebrush communities and their obligate wildlife species. Extensive drought-induced mortality has been documented in pinyon-juniper systems in the Southwest, and these communities may be further impacted by increased intensity and duration of future droughts (Breshears et al. 2005; Williams et al. 2012). This vegetation type may expand in the Great Basin and Front Range of Colorado with warmer temperatures, but will likely be replaced by more arid desert scrub and grassland communities in northern Arizona and New Mexico (Finch 2012). This could impact at-risk bird species such as the pinyon jay (Gymnorhinus cyanocephalus) and gray vireo (Vireo vicinior) that occur at several DoD installations in the region (e.g., Kirkland Air Force Base and Army National Guard Camel Tracks Training Area, New Mexico; Johnson et al. 2011).

Warm-temperate and subtropical desert life zones will also be affected by rising temperatures, although predictions 

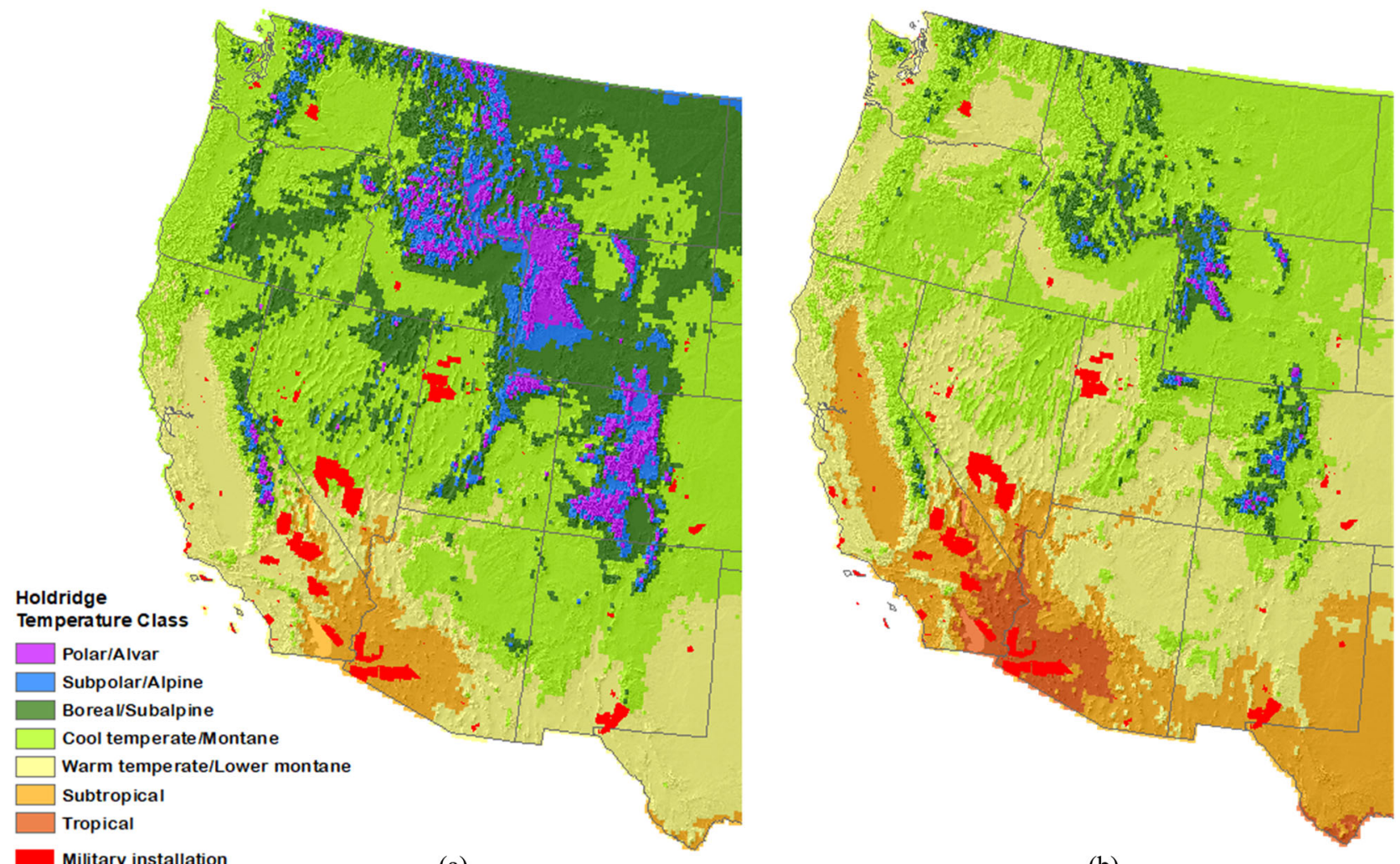

(a)

(b)

Fig. 7 Holdridge temperature classes for the western USA based on mean annual temperature from 1951 to 2006 (a) and projected mean annual temperature in 2085 under the A2 high emissions scenario (b). Data source: ClimateWizard, www.climatewizard.org (Girvetz et al. 2009)

of changes in species distributions based on bioclimatic models remain approximate due to uncertainties associated with future precipitation patterns (e.g., summer monsoon) and winter temperature regimes (Abatzoglou and Kolden 2011). However, in general, climate in the southwestern US is expected to become substantially warmer and drier (superarid in the Holdridge Life Zone classification) with periodic drought conditions exceeding those experienced in the past several hundred years (Seager et al. 2007). Species whose ranges are currently limited by freezing temperatures are expected to migrate northward and to higher elevations in Southwest mountains, eventually displacing more coldtolerant species and plant communities. At lower elevations, desert scrub communities are projected to continue as the dominant vegetation type and may expand northward and eastward (Weiss and Overpeck 2005), while isolated montane forests (e.g., Madrean forest and woodlands) are projected to completely disappear over time (Rehfeldt et al. 2006). There is concern that milder winters in combination with more intense summer drought conditions will favor the establishment of frost-intolerant, exotic annual grasses (e.g., Bromus rubens, Pennisetum ciliare, and Eragrostis lehmanniana) in the Mojave and Sonoran deserts in the Southwest that would introduce surface fuels and potentially establish fire regimes that most native desert species are not adapted to. Warmer temperatures could also alter synchronicity between pollinators and flowering plants potentially affecting many insect, bird, and bat species (Memmott et al. 2007). Bagne and Finch (2012, 2013) identified a number of animal and plant species at the Barry M. Goldwater Range and Fort Huachuca, Arizona that illustrate the potentially wide-ranging impacts of climate change on military installations located in southwest desert ecosystems, including the endangered Mexican long-nosed bat (Leptonycteris nivalis), lesser long-nosed bat (Leptonycteris yerbabuenae), and Sonoran pronghorn antelope (Antilocapra americana sonoriensis).

\section{Conclusions}

Based on projections from an ensemble of 16 GCMs, military installations within humid boreal to cool temperate forest biomes in the northeastern US and subhumid cool temperate steppe biomes in the northern Great Plains are most vulnerable to significant shifts in MAT and/or MAP over the next 60-70 years. Installations in the northern Great Plains and Lake States could see increases in MAP on the order of $10-13 \%$, which may mitigate some aspects of increasing temperature on biological systems, whereas 
installations in the Southwest that are already water-stressed are projected to receive 5-10\% less precipitation by 2085 under the A2 emission scenario. All biomes in North America are projected to be impacted by increasing MATs to some degree, but biological systems in relatively colder climates at higher latitudes and at higher elevations may experience the largest proportional increases in MAT and mean annual evapotranspiration in comparison with current conditions. Significant impacts on biological systems are likely even under less severe future emission scenarios (A1B and B1 relative to A2) and over shorter time frames. Significant northward shifts of major life zones in the eastern US may occur as early as 2055 under all emission scenarios. Even under the less severe $\mathrm{CO}_{2}$ emission models, over half of the boreal life zone is projected to be lost from the eastern US, and subtropical conditions may expand from the immediate Gulf Coast to eastern North Carolina and southeastern Oklahoma by 2055.

Most military installations do not encompass large elevational gradients, especially those located in the eastern US, and are therefore not likely to experience wholesale changes in tree species assemblages in the next 50 years. However, it is likely that the relative frequency and abundance of some tree species will change and adversely affect boreal species more than temperate species. As a result, installations in boreal and cold temperate life zones during Sikes Act's Integrated Natural Management Planning tasks and National Environmental Policy Act analyses for project clearance may find implementing more frequent biological monitoring programs useful to determine the extent to which projected changes in species composition and other ecosystem properties are occurring. Proactive multicontingency planning for stewardship work seems prudent based on predicted future trajectories for installations. Despite the projected rapid changes in atmospheric temperature, current research indicates that changes in biological communities will occur more slowly and may be difficult to observe. However, there is also evidence that some species may have temperature-related "tipping points" where various biological processes (e.g., root growth and seed production) are disrupted and could significantly affect growth rates and regeneration over a short time span as ecological thresholds are approached, such as species already at the southernmost portion of their distribution (Odom and Ford 2020). Changes in species composition should have relatively little impact on military training objectives per se as long as basic structural components of land cover remain manageable, although installations with currently at-risk or endangered species may face additional management challenges meeting Endangered Species Act requirements for species susceptible to climate-change stressors. Typically, training does not depend on a particular plant species mix as much as a particular vegetation physiognomy. However, if predicted increases in precipitation do not materialize in ecoregions where future MATs are expected to be relatively high such as the southeastern US, or if species respond differently than predicted by coarse-scale bioclimatic models, forest communities may develop in very different directions and create novel communities with few current analogs. For example, despite the current humid climate and potential for increased precipitation projected by some climate models in the southeastern US, Clark et al. (2014) and McNulty et al. (2013) observed that higher evapotranspiration rates, more intense drought events, and increased frequency of wildfires in the future could drive southern pine forests toward subtropical pine-savanna vegetation, which would have profound impacts on biological communities, economies, and land use patterns in the region-and in this case perhaps military training.

\section{Data availability}

Data are available on request from authors.

Acknowledgements Special thanks to S. Brasfield, N. Bean, and E. Britzke for project assistance throughout this effort. M. Adams and G. Nowacki reviewed an earlier draft of this paper. Funding for this work was provided by the U.S. Army Engineer Research and Development Center's Environmental Quality and Installation Research Program to Virginia Polytechnic Institute and State University.

Funding This project was funded by the U.S. Army Engineer Research and Development Center's Environmental Quality and Installation Research Program.

Author Contributions WMF acquired project support. RHO and WMF co-designed the study. RHO was responsible for data analysis and interpretation. RHO and WMF co-wrote the paper.

\section{Compliance with Ethical Standards}

Conflict of Interest The authors declare that they have no conflict of interest.

Consent for Publication Both authors, U.S. Geological Survey, the U.S. Army Corps of Engineers, and Virginia Polytechnic Institute and State University support publication.

Publisher's note Springer Nature remains neutral with regard to jurisdictional claims in published maps and institutional affiliations.

\section{Appendix}


Table 3 Department of defense installations in the continental United States (Source: Military Installations, Ranges, and Training Areas (point locations and boundaries), Version 1.0, June 21, 2010, accessed 11/16/2012 from http://www.acq.osd.mil/ie/bei/opengov/installations_ranges.zip)

\begin{tabular}{|c|c|c|c|c|c|}
\hline Code & Installation name & Latitude (degrees) & Longitude (degrees) & Mean annual temperature $\left({ }^{\circ} \mathrm{C}\right)$ & Mean annual precipitation (mm) \\
\hline 29PA & Twentynine Palms Marine Corps Base & 34.4400 & -116.1117 & 20.1 & 114.3 \\
\hline ABER & Aberdeen Proving Ground & 39.3415 & -76.2908 & 13.3 & 1122.7 \\
\hline ADAI & Camp Adair Military Reservation & 44.7155 & -123.2747 & 11.5 & 1110.0 \\
\hline ANNI & Anniston Army Depot & 33.7120 & -85.9575 & 16.9 & 1318.3 \\
\hline ARLG & Arlington National Cemetery & 38.8773 & -77.0723 & 13.2 & 1036.3 \\
\hline AROT & Army Reserve Outdoor Training Area & 41.1441 & -96.4138 & 10.4 & 767.1 \\
\hline ATAN & Army Training Area (NE) & 41.3082 & -98.3110 & 9.9 & 657.9 \\
\hline ATTE & Camp Atterbury Military Reservation & 39.3091 & -86.0409 & 11.7 & 1066.8 \\
\hline AVON & Avon Park Air Force Bombing Range & 27.6470 & -81.2919 & 22.2 & 1247.1 \\
\hline BADG & Badger Army Ammunition Plant & 43.3594 & -89.7360 & 6.3 & 858.5 \\
\hline BARS & Barstow Marine Corps Logistics Base & 34.8655 & -116.9427 & 18.7 & 109.2 \\
\hline BEAR & Bearmouth National Guard TA & 46.7021 & -113.3125 & 5.9 & 320.0 \\
\hline BEAU & Beaufort Marine Corps Air Station & 32.4734 & -80.7157 & 18.7 & 1264.9 \\
\hline BELL & Belle Mead General Depot & 40.4882 & -74.6682 & 11.4 & 1237.0 \\
\hline BELV & Fort Belvoir Military Reservation & 38.7153 & -77.1665 & 13.2 & 1036.3 \\
\hline BENN & Fort Benning Military Reservation & 32.3967 & -84.8273 & 18.4 & 1234.4 \\
\hline BLIS & Fort Bliss & 31.8977 & -106.2594 & 18.2 & 239.5 \\
\hline BOGU & Bogue Field & 34.6940 & -77.0288 & 17.6 & 1478.3 \\
\hline BRAG & Fort Bragg Military Reservation & 35.1521 & -79.1380 & 16.2 & 1186.2 \\
\hline BUCK & Buckley Air National Guard AF Base & 39.7073 & -104.7639 & 10.0 & 401.3 \\
\hline BULL & Camp Bullis & 29.6778 & -98.5810 & 20.4 & 835.7 \\
\hline CAMP & Fort Campbell & 36.6296 & -87.6210 & 14.4 & 1318.3 \\
\hline CARS & Fort Carson Military Reservation & 37.4910 & -103.8746 & 9.4 & 421.6 \\
\hline CHPT & Cherry Point Marine Corps Air Sta & 34.9239 & -76.8953 & 16.8 & 1389.4 \\
\hline CNWS & Crane Naval Weapons Support Ctr & 38.8348 & -86.7953 & 11.9 & 1127.8 \\
\hline CORN & Cornhusker Army Ammunition Plant & 40.9254 & -98.3866 & 9.9 & 657.9 \\
\hline CUSI & Cusick Survival Training Site & 48.4917 & -117.4233 & 8.2 & 556.3 \\
\hline CUST & Custer Reserve Forces Training Area & 42.3041 & -85.3253 & 8.9 & 894.1 \\
\hline DARE & Dare County Range & 35.7167 & -75.8846 & 16.6 & 1310.6 \\
\hline DETR & U.S. Garrison, Fort Detrick & 39.4369 & -77.4524 & 13.4 & 1031.2 \\
\hline DODG & Camp Dodge Military Reservation & 41.7159 & -93.7253 & 10.0 & 881.4 \\
\hline DRUM & Fort Drum & 44.1331 & -75.6083 & 7.4 & 1082.0 \\
\hline DUGW & Dugway Proving Grounds & 40.2261 & -113.0440 & 11.2 & 419.1 \\
\hline EGLN & Eglin AFB & 30.5822 & -86.5494 & 20.1 & 1632.7 \\
\hline ELLS & Ellsworth AFB & 44.1552 & -103.0916 & 7.4 & 467.4 \\
\hline ETAL & Fort Ethan Allen Military Reservation & 44.4679 & -72.8999 & 7.3 & 915.7 \\
\hline EUST & Fort Eustis Military Reservation & 37.1261 & -76.5891 & 14.8 & 1247.1 \\
\hline FDIX & Fort Dix Military Reservation & 39.9942 & -74.5360 & 12.2 & 1196.8 \\
\hline FLEE & Fort Lee Military Reservation & 37.2518 & -77.3321 & 13.9 & 1150.6 \\
\hline FLOR & Florence Military Reservation & 33.0920 & -111.3488 & 20.9 & 254.0 \\
\hline FORD & Fort Ord Military Reservation & 36.6319 & -121.7656 & 14.1 & 393.7 \\
\hline GILL & Fort Gillem & 33.6219 & -84.3292 & 16.3 & 1196.3 \\
\hline GOOD & Goodfellow AFB & 31.4361 & -100.3651 & 18.0 & 530.9 \\
\hline GORD & Fort Gordon & 33.3572 & -82.2384 & 17.3 & 1130.3 \\
\hline GRAY & Camp Grayling Military Reservation & 44.6178 & -84.8820 & 5.4 & 848.4 \\
\hline GRFO & Grand Forks AFB & 47.9608 & -97.2473 & 4.6 & 497.8 \\
\hline HAAD & Hawthorne Army Ammunition Depot & 39.4320 & -76.1755 & 13.3 & 114.3 \\
\hline HIGH & Highlands, NC & 35.0545 & -83.2021 & 10.3 & 2225.0 \\
\hline HILL & Fort A.P. Hill Military Reservation & 38.1210 & -77.2668 & 13.6 & 1130.3 \\
\hline HNLG & Hunter-Liggett Military Reservation & 35.9633 & -121.1741 & 15.6 & 312.4 \\
\hline HOME & Homestead AFB & 25.4980 & -80.3893 & 23.8 & 1486.7 \\
\hline HOOD & Fort Hood & 31.1762 & -97.6910 & 20.2 & 854.7 \\
\hline HUAC & Fort Huachuca & 31.5609 & -110.3157 & 17.4 & 360.7 \\
\hline IOWA & Iowa Army Ammunition Plant & 40.7893 & -91.2503 & 10.9 & 962.7 \\
\hline IRWN & Fort Irwin & 35.3779 & -116.6227 & 20.1 & 114.0 \\
\hline
\end{tabular}


Table 3 (continued)

\begin{tabular}{|c|c|c|c|c|c|}
\hline Code & Installation name & Latitude (degrees) & Longitude (degrees) & Mean annual temperature $\left({ }^{\circ} \mathrm{C}\right)$ & Mean annual precipitation $(\mathrm{mm})$ \\
\hline JACK & Fort Jackson & 34.0394 & -80.8341 & 18.9 & 1196.3 \\
\hline JOLI & Joliet Army Ammunition Plant & 41.3859 & -88.1238 & 9.7 & 937.3 \\
\hline KAAP & Kansas Army Ammunition Plant & 37.2917 & -95.2067 & 13.4 & 1069.3 \\
\hline KING & Kingsville NAS & 27.4983 & -97.8258 & 22.0 & 736.6 \\
\hline KNOX & Fort Knox & 37.8980 & -85.9023 & 13.2 & 1270.0 \\
\hline LAOP & Louisiana Ordnance Plant & 32.5651 & -93.4000 & 18.7 & 1303.0 \\
\hline LAUG & Laughlin AFB & 29.3594 & -100.7826 & 20.9 & 475.0 \\
\hline LCAP & Lake City Army Ammunition Plant & 39.0968 & -94.2489 & 11.9 & 1097.3 \\
\hline LEAV & Fort Leavenworth Military Reservation & 39.3613 & -94.9095 & 12.2 & 1038.9 \\
\hline LEJE & Camp Lejeune Marine Corps Base & 34.6504 & -77.3179 & 16.8 & 1389.4 \\
\hline LEOW & Fort Leonard Wood Military Reservation & 37.7014 & -92.1549 & 12.9 & 1130.3 \\
\hline LETT & Letterkenny Army Depot & 40.0199 & -77.6972 & 11.3 & 1011.7 \\
\hline LEWI & Fort Lewis Military Reservation & 47.0297 & -122.5964 & 11.5 & 990.6 \\
\hline LONG & Longhorn Ordnance Ammo Plant & 32.6695 & -94.1368 & 17.6 & 1300.5 \\
\hline MACD & MacDill AFB & 27.8433 & -82.5012 & 22.8 & 1137.9 \\
\hline MACK & Camp MacKall Military Reservation & 35.0284 & -79.4921 & 16.2 & 1186.2 \\
\hline MACR & Fort MacArthur & 33.7133 & -118.2979 & 17.4 & 334.0 \\
\hline MALA & Malabar Transmitter Annex & 28.0228 & -80.6797 & 22.3 & 1226.8 \\
\hline MALM & Malmstrom AFB & 47.5082 & -111.1868 & 6.5 & 378.5 \\
\hline MANG & Mead Army National Guard Facility & 41.1951 & -96.4382 & 10.4 & 767.1 \\
\hline MCLS & Marine Corps Logistics Support Base & 31.5528 & -84.0509 & 18.6 & 1356.4 \\
\hline MCOY & Fort McCoy & 44.0303 & -90.6853 & 7.0 & 838.2 \\
\hline МCPH & Fort McPherson & 33.7072 & -84.4353 & 16.3 & 1196.3 \\
\hline MEAD & Fort George G. Meade & 39.1022 & -76.7448 & 13.3 & 1178.6 \\
\hline MELR & Melrose Air Force Range & 34.3096 & -103.7883 & 14.3 & 469.9 \\
\hline MHAB & Mountain Home Air Base & 43.0568 & -115.8701 & 10.3 & 269.2 \\
\hline MILA & Milan Arsenal & 35.8845 & -88.7016 & 13.7 & 1379.2 \\
\hline MINO & Minot AFB & 48.4207 & -101.3461 & 5.3 & 469.9 \\
\hline MONM & Fort Monmouth Military Reservation & 40.3129 & -74.0471 & 11.6 & 1237.0 \\
\hline MONR & Fort Monroe Military Reservation & 37.0171 & -76.2985 & 15.3 & 1163.3 \\
\hline MTBA & Mount Baker Helicopter Training Area & 48.9318 & -121.9750 & 10.1 & 2057.4 \\
\hline NAAP & Newport Army Ammunition Plant & 39.7955 & -87.4000 & 12.1 & 1137.9 \\
\hline NAPE & Army Helicopter Training Area & 46.7356 & -122.6127 & 11.8 & 1206.5 \\
\hline NATI & Natick Laboratories Military Reserv & 42.4012 & -71.4719 & 10.1 & 1245.9 \\
\hline NAVA & Navajo Army Depot (Closed) & 35.1886 & -111.7848 & 5.7 & 589.3 \\
\hline NOLA & New Orleans Naval Air Station & 29.8452 & -89.9938 & 20.9 & 1612.9 \\
\hline NSTF & Naval Survival Training Facility & 44.9865 & -70.4465 & 3.4 & 1031.2 \\
\hline OAAP & U.S. Army Ammunition Depot (OK) & 34.8176 & -95.9302 & 16.5 & 1150.6 \\
\hline OTSP & Military Ocean Terminal Sunny Point & 34.0082 & -77.9715 & 17.7 & 1450.3 \\
\hline PAIS & Parris Island U.S. Marine Corps & 32.3357 & -80.7096 & 18.7 & 1264.9 \\
\hline PARK & Camp Parks Military Reservation & 37.7215 & -121.8974 & 15.4 & 375.9 \\
\hline PEND & Camp Pendleton Marine Corps Base & 33.3546 & -117.4211 & 16.1 & 281.9 \\
\hline PIBL & Pine Bluff Arsenal & 34.3230 & -92.0789 & 16.1 & 1318.3 \\
\hline PICA & Picatinny Arsenal & 40.9555 & -74.5419 & 9.1 & 1219.2 \\
\hline PICK & Fort Pickett Military Reservation (VNG) & 37.0455 & -77.9151 & 13.8 & 1165.9 \\
\hline POLK & Fort Polk Military Reservation & 31.0883 & -93.0586 & 19.2 & 1602.2 \\
\hline POWE & Powell Air Force Sta & 44.7693 & -108.3048 & 6.9 & 170.2 \\
\hline PUEB & Pueblo Army Depot & 38.3139 & -104.3301 & 11.9 & 330.2 \\
\hline QUAN & Quantico Marine Corps Base & 38.5616 & -77.4265 & 13.3 & 1087.1 \\
\hline RAAP & Radford Army Ammunition Plant & 37.1847 & -80.5454 & 10.6 & 1082.0 \\
\hline RAVE & Ravenna Arsenal & 41.1974 & -81.0760 & 8.8 & 960.1 \\
\hline REDR & Red River Army Depot & 33.4258 & -94.2983 & 17.1 & 1300.5 \\
\hline REDS & Redstone Arsenal & 34.6285 & -86.6026 & 15.9 & 1460.5 \\
\hline RILE & Camp Riley Military Reservation & 46.1308 & -123.9451 & 10.6 & 1704.3 \\
\hline RILY & Fort Riley Military Reservation & 39.1669 & -96.8112 & 12.7 & 883.9 \\
\hline RIPL & Camp Ripley MNG & 46.0889 & -94.3590 & 4.8 & 674.0 \\
\hline
\end{tabular}


Table 3 (continued)

\begin{tabular}{|c|c|c|c|c|c|}
\hline Code & Installation name & Latitude (degrees) & Longitude (degrees) & Mean annual temperature $\left({ }^{\circ} \mathrm{C}\right)$ & Mean annual precipitation (mm) \\
\hline ROBE & Camp Roberts Military Reservation & 35.7888 & -120.7869 & 15.6 & 309.9 \\
\hline ROBI & Camp Joseph T. Robinson & 34.8885 & -92.3095 & 16.2 & 1237.0 \\
\hline ROCK & Rock Island Arsenal & 41.5168 & -90.5421 & 10.6 & 894.1 \\
\hline RUCK & Fort Rucker Military Reservation & 31.4119 & -85.7408 & 18.7 & 1445.3 \\
\hline SAAP & Sunflower Army Ammunition Plant & 38.9226 & -95.0096 & 13.6 & 1010.9 \\
\hline SENE & Seneca Army Depot & 42.7434 & -76.8594 & 8.9 & 848.4 \\
\hline SHAR & Sharpe General Depot (Field Annex) & 37.8360 & -121.2641 & 16.1 & 421.6 \\
\hline SIER & Sierra Army Depot & 40.2371 & -120.2576 & 9.5 & 340.4 \\
\hline SILL & Fort Sill Military Reservation & 34.7024 & -98.5176 & 16.3 & 802.6 \\
\hline SMOK & Smoky Hill ANG Range & 38.6986 & -97.8128 & 13.2 & 817.9 \\
\hline SNOQ & Snoqualmie National Forest & 47.0468 & -121.6122 & 9.8 & 1468.1 \\
\hline STEW & Fort Stewart & 31.9868 & -81.5970 & 19.8 & 1229.4 \\
\hline STOR & Fort Story Military Reservation & 36.9212 & -76.0192 & 15.3 & 1163.3 \\
\hline SWIF & Camp Swift N. G. Facility & 30.2202 & -97.2465 & 20.2 & 854.7 \\
\hline TINK & Tinker AFB & 35.4150 & -97.3973 & 15.6 & 911.9 \\
\hline TOAD & Tooele Army Depot & 40.5282 & -112.4047 & 11.0 & 500.4 \\
\hline UMAT & Umatilla Chemical Depot & 45.8396 & -119.4405 & 11.7 & 264.2 \\
\hline VAND & Vandenberg AFB & 34.7219 & -120.5568 & 15.4 & 401.3 \\
\hline WIHA & Fort William H. Harrison & 46.6311 & -112.1046 & 6.7 & 287.0 \\
\hline WILU & Camp Williams, UT & 40.4498 & -112.0123 & 11.4 & 325.1 \\
\hline WILW & Camp Williams, WI & 43.9384 & -90.2521 & 6.9 & 845.8 \\
\hline WOLT & Fort Wolters & 32.8732 & -97.9940 & 19.1 & 807.7 \\
\hline WSMR & White Sands Missile Range & 32.9537 & -106.4183 & 16.2 & 335.3 \\
\hline WSPT & West Point U.S. Military Academy & 41.3639 & -74.0300 & 10.6 & 1287.8 \\
\hline YAKI & Yakima Firing Center & 46.7098 & -120.1944 & 9.4 & 210.8 \\
\hline YUMA & Yuma Proving Ground & 33.1587 & -114.4203 & 23.9 & 78.7 \\
\hline
\end{tabular}

Table 4 General circulation models (GCM) available at Climatewizard.org that were used collectively to generate temperature and precipitation projections to formulate Holdridge Life Zones (Girvetz et al. 2009)

\begin{tabular}{lll}
\hline Model & Country & Organization \\
\hline BCCR-BCM2.0 & Norway & Bjerknes Centre for Climate Research \\
CGCM3.1(T47) & Canada & Canadian Centre for Climate Modelling \& Analysis \\
CNRM-CM3 & France & Météo-France/Centre National de Recherches Météorologiques \\
CSIRO-Mk3.0 & Australia & CSIRO Atmospheric Research \\
GFDL-CM2.0 & USA & U.S. Dept. of Commerce/ NOAA/ Geophysical Fluid Dynamics Laboratory \\
GFDL-CM2.1 & USA & U.S. Dept. of Commerce/NOAA/ Geophysical Fluid Dynamics Laboratory \\
GISS-ER & USA & NASA/ Goddard Institute for Space Studies \\
INM-CM3.0 & Russia & Institute for Numerical Mathematics \\
IPSL-CM4 & France & Institute Pierre Simon Laplace \\
MIROC3.2(medres) & Japan & Center for Climate System Research (The University of Tokyo), National \\
& & Institute for Environmental Studies, and Frontier Research Center for Global \\
ECHO-G & Change (JAMSTEC) \\
ECHAM5/MPI-OM & Germany/Korea & Meteorological Institute of the University of Bonn, Meteorological Research \\
MRI-CGCM2.3.2 & & Institute of KMA, and Model and Data group \\
CCSM3 & Germany & Max Planck Institute for Meteorology \\
PCM & Japan & Meteorological Research Institute \\
UKMO-HadCM3 & USA & National Center for Atmospheric Research \\
\hline
\end{tabular}




\section{References}

Abatzoglou JT, Kolden CA (2011) Climate change in western US deserts: potential for increased wildfire and invasive annual grasses. Range Ecol Manag 64:471-478

AchutaRao K, Covey C, Doutriaux C, Fiorino M, Gleckler P, Phillips T, Sperber K, Taylor K (2004) An appraisal of coupled climate model simulations. Bader D, ed. Lawrence Livermore National Laboratory, UCRL-TR-202550, August 16, 2004, 197pp. http://www-pcmdi.llnl.gov/appraisal.php. Accessed 10 April 2017

Alexander HD, Arthur MA (2014) Increasing red maple leaf litter alters decomposition rates and nitrogen cycling in historically oak-dominated forests of the eastern. U S Ecosys 17:1371-1383

Araujo MB, Pearson RG, Thuiller W, Erhard M (2005) Validation of species-climate impact models under climate change. Glob Change Biol 11:1504-1513

Bagne KE, Finch DM (2012) Vulnerability of species to climate change in the Southwest: threatened, endangered, and at-risk species at the Barry M. Goldwater Range, Arizona. Gen. Tech. Rep. RMRSGTR-284. U.S. Department of Agriculture, Forest Service, Rocky Mountain Research Station, Fort Collins, CO, p 139

Bagne KE, Finch DM (2013) Vulnerability of species to climate change in the Southwest: threatened, endangered, and at-risk species at Fort Huachuca, Arizona. Gen. Tech. Rep. RMRSGTR-302. U.S. Department of Agriculture, Forest Service, Rocky Mountain Research Station, Fort Collins, CO, p 183

Balmaseda MA, Trenberth KE, Källén E (2013) Distinctive climate signals in reanalysis of global ocean heat content. Geophys Res Lett 40:1754-1759

Beckage B, Osborne B, Gavin DG, Pucko C, Siccama T, Perkins T (2008) A rapid upward shift of a forest ecotone during 40 years of warming in the Green Mountains of Vermont. Proc Natl Acad Sci 105(11):4197-4202

Bergengren JC, Waliser DE, Yung YL (2011) Ecological sensitivity: a biospheric view of climate change. Climatic Change 107:433-457

Blomberg EJ, Sedinger JS, Atamian MT, Nonne DV (2012) Characteristics of climate and landscape disturbance influence the dynamics of greater sage-grouse populations. Ecosphere 3(6):55

Bonan GB (2008) Forests and climate change: forcings, feedbacks, and the climate benefits of forests. Sci 320:1444-1449

Botkin DB, Saxe H, Araújo MB, Betts R, Bradshaw RHW, Cedhagen T, Chesson P, Dawson TP, Etterson JR, Faith DP, Ferrier S, Guisan A, Hansen AS, Hilbert DW, Loehle C, Margules C, New M, Sobel MJ, Stockwell DRB (2007) Forecasting the effects of global warming on biodiversity. BioSci 57:227-236

Braun E (1950) Deciduous forests of eastern North America: The Blakiston Co., Philadelphia, 596 p

Breshears DD, Cobb NS, Rich PM, Price KP, Allen CD, Balice RG, Romme WH, Kastens JH, Floyd ML, Belnap J, Anderson JJ, Myers OB, Meyer CW (2005) Regional vegetation die-off in response to global-change type drought. Proc Nat Acad Sci 102:15144-15148

Briggs JM, Knapp AK, Blair JM, Heisler JL, Hoch GA, Lett MS, McCarron JK (2005) An ecosystem in transition: causes and consequences of the conversion of mesic grassland to shrubland. BioSci 55:243-254

Campbell JL, Rustad LE, Boyer W, Christopher SF, Driscoll CT, Fernandez IJ, Groffman PM, Houle D, Kiekbusch J, Magill AH, Mitchell MJ, Scott V, Ollingeri SV (2009) Consequences of climate change for biogeochemical cycling in forests of northeastern North America. Can J Res 39:264-284

Canham CD, Thomas RQ (2010) Frequency, not relative abundance, of temperate tree species varies along climate gradients in eastern North America. Ecol 91(12):3433-3440
Clark JS (1998) Why trees migrate so fast: confronting theory with dispersal biology and the paleorecord. Am Nat 152:204-224

Clark JS, Carpenter SR, Barber M, Collins S, Dobson A, Foley JA, Lodge DM, Pascual M, Pielke Jr R, Pizer W, Pringle C, Reid WV, Rose KA, Sala O, Schlesinger WH, Wall DH, Wear D (2001) Ecological forecasts: an emerging imperative. Sci 293 (5530):657-660

Clark JS, Gelfand AE, Woodall CW, Zhu K (2014) More than the sum of the parts: forest climate response from joint species distribution models. Ecol Appl 24(5):990-999

Cleland DT, Avers PE, McNab WH, Jensen ME, Bailey RG, King T, Russell WE (1997) National hierarchical framework of ecological units. In: Boyce MS, Haney A (eds.) Ecosystem Management Applications for Sustainable Forest and Wildlife Resources. Yale University Press, New Haven, p 181-200

Comer PJ, Faber-Langendoen D, Evans R, Gawler SC, Josse C, Kittel G, Menard S, Pyne M, Reid M, Schulz K, Snow K, Teague J (2003) Ecological systems of the United States: a working classification of U.S. terrestrial systems. NatureServe, Arlington, VA

Cook BI, Ault TR, Smerdon JE (2015) Unprecedented $21^{\text {st }}$ century drought risk in the American Southwest and Central Plains. SciAdv 1(Feb):e1400082

Crimmins SM, Dobrowski SZ, Greenberg JA, Abatzoglou JT, Mynsberge AR (2011) Changes in climatic water balance drive downhill shifts in plant species' optimum elevations. Sci 331:324-327

Dale VH, Tharp ML, Lannom KO, Hodges DG (2010) Modeling transient response of forests to climate change. Sci Total Environ 408:1888-1901

Daly C, Neilson RP, Phillips DL (1994) A statistical-topographic model for mapping climatological precipitation over mountainous terrain. J Appl Meteor 33:140-158

Daly C, Halbleib M, Smith JI, Gibson WP, Doggett MK, Taylor GH, Curtis J, Pasteris PA (2008) Physiographically-sensitive mapping of temperature and precipitation across the conterminous United States. Int J Climatol 28:2031-2064

Davis MB, Shaw RG (2001) Range shifts and adaptive responses to Quaternary climate change. Sci 292(5517):673-679

Deser C, Knutti R, Solomon S, Phillips AS (2012) Communication of the role of natural variability in future North American climate. Nat Clim Change 2:775-779

Dukes JS, Pontius J, Orwig DA, Garnas JR, Rodgers VL, Brazee NJ, Cooke BJ, Theoharides KA, Stange EE, Harrington RA, Ehrenfeld JG, Gurevitch J, Lerdau M, Stinson K, Wick R, Ayres MP (2009) Responses of insect pests, pathogens, and invasive plant species to climate change in the forests of northeastern North America: What can we predict? in NE Forests 2100: a synthesis of climate change impacts on forests of the Northeastern U.S. and Eastern Canada. Can J For Res 39:231-248

Duveneck MJ, Scheller RM, White MA, Handler SD, Ravenscroft C (2014) Climate change effects on northern Great Lake (USA) forests: a case for preserving diversity. Ecosphere 5:1-20

Dyer JM (2006) Revisiting the deciduous forests of eastern North America. BioSci 56:341-352

Elliott GP (2012) Extrinsic regime shifts drive abrupt changes in regeneration dynamics at upper treeline in the Rocky Mountains, USA. Ecology 93(7):1614-1625

Emanuel WR, Shugart HH, Stevenson MP (1985) Climate change and the broad-scale distribution of terrestrial ecosystem complexes. Clim Change 7:29-43

ERDC (2010) Climate change-induced biome shifts and contaminant management for DoD lands, Project Management Plan 6.2/6.3. Unpublished internal document available from U.S. Army Corps of Engineers. Engineer Research and Development Center, Environmental Lab, Vicksburg, MS, p 22 
Fangxing F, Bradley RS, Rawlins MA (2013) Climate change in the northeastern U.S.: regional climate model validation and climate change projections. Clim Dynam 43:145-161

Finch DM (2012) Climate change in grasslands, shrublands, and deserts of the interior American West: a review and needs assessment. Gen. Tech. Rep. RMRS-GTR-285. U.S. Department of Agriculture, Forest Service, Rocky Mountain Research Station, Fort Collins, CO, p 139

Foster DR, Motzkin G, Slater B (1998) Land-use history as long-term broad-scale disturbance: regional forest dynamics in central New England. Ecosys 1:96-119

Frost C (2006) History and future of the longleaf pine ecosystem. In: Jose S, Jokela EJ, Miller DL (eds) The longleaf pine ecosystem: ecology, silviculture, and restoration. Springer, New York, NY, p 9-49

Gibson WP, Daly C, Kittel T, Nychka D, Johns C, Rosenbloom N, McNab A, Taylor G (2002) Development of a 103-year highresolution climate data set for the conterminous United States. Proc.13th AMS Conf. Appl Clim 16:181-183

Girvetz EH, Zganjar C, Raber GT, Maurer EB, Kareiva P, Lawler JL (2009) Applied climate-change analysis: The Climate Wizard Tool. PLoS ONE 4(12):e8320. https://doi.org/10.1371/journal. pone.0008320.

Gleckler PJ, Taylor KE, Doutriaux C (2008) Performance metrics for climate models. J Geophys Res 113:D06104. https://doi.org/10. 1029/2007JD008972

Grzybowski JA, Tazik DJ, Schnell GD (1994) Regional analysis of black-capped vireo breeding habitats. Condor 96:512-544

Guisan A, Thuiller W (2005) Predicting species distribution: offering more than simple habitat models. Ecol Lett 8:993-1009

Hall A (2014) Projecting regional change. Sci 346(6216):1461-1462

Hamburg SP, Cogbill CV (1988) Historical decline of red spruce populations and climatic warming. Nature 331(6155):428-431

Hanberry B, Palik B, He H (2012) Comparison of historical and current forest surveys for detection of homogenization and mesophication of Minnesota forests. Land Ecol 27:1495-1512

Hansen AJ, Neilson RP, Dale VH, Flather CH, Iverson LR, Currie DJ, Shafer S, Cook R, Bartlein PJ (2001) Global change in forests: responses of species, communities, and biomes: interactions between climate change and land use are projected to cause large shifts in biodiversity. BioSci 51:765-779

Hayhoe K, Wake CP, Huntington TG, Luo L, Schwartz MD, Sheffield J, Wood E, Anderson B, Bradbury J, DeGaetano A, Troy TJ, Wolfe D (2007) Past and future changes in climate and hydrological indicators in the U.S. Northeast. Clim Dyn 28:381-407

Herr A, Dambacher JM, Pinkard E, Glen M, Mohammed C, Wardlaw $\mathrm{T}$ (2016) The uncertain impact of climate change on forest ecosystems-How qualitative modelling can guide future research for quantitative model development. Envir Model Softw 76:95-107

Hinzman LD, Bettez ND, Bolton WR, Chapin FS, Dyurgerov MB, Fastie CL, Griffith B, Hollister RD, Hope A, Huntington HP, Jensen AM, Jia GJ, Jorgenson T, Kane DL, Klein DR, Kofinas G, Lynch AH, Lloyd AH, McGuire AD, Nelson FE, Oechel WC, Osterskamp TE, Racine CH, Romanovsky VE, Stone RS, Stow DA, Sturm M, Tweedie CE, Vourlitis GL, Walker MD, Walker DA, Webber PJ, Welker JM, Winker KS, Yoskikawa K (2005) Evidence and implications of recent climate change in northern Alaska and other Arctic Regions. Climatic Change 72 (3):251-298

Hof C, Levinsky I, Araujo MB, Rahbek C (2011) Rethinking species' ability to cope with rapid climate change. Glob Change Biol 17:2987-2990

Holdridge LR (1947) Determination of world plant formations from simple climatic data. Sci 108:367-368
Holdridge LR (1965) Life zone ecology, Revised Edition. Tropical Science Center, San Jose, Costa Rica, p 149

Hovick TJ, Elmore RD, Allred BW, Fuhlendorf SD, Dahlgren DK (2014) Landscapes as a moderator of thermal extremes: a case study from an imperiled grouse. Ecosphere https://doi.org/10. 1890/ES13-00340.1

Huntington TG, Richardson AD, McGuire KJ, Hayhoe K (2009) Climate and hydrological changes in the northeastern United States: recent trends and implications for forested and aquatic ecosystems. Can J Res 39:199-212

Intergovernmental Panel on Climate Change (IPCC) (2007) Climate change 2007: synthesis report. contribution of working groups I, II and III to the Fourth Assessment Report of the Intergovernmental Panel on Climate Change [Core Writing Team, Pachauri RK, Reisinger A (eds.)]. IPCC, Geneva, Switzerland, p 104

Intergovernmental Panel on Climate Change (IPCC) (2014) Summary for policymakers. In: Field CB, Barros VR, Dokken DJ, Mach KJ, Mastrandrea MD, Bilir TE, Chatterjee M, Ebi KL, Estrada YO, Genova RC, Girma B, Kissel ES, Levy AN, MacCracken S, Mastrandrea PR, White LL (eds.) Climate Change 2014: Impacts, Adaptation, and Vulnerability. Part A: Global and Sectoral Aspects. Contribution of Working Group II to the Fifth Assessment Report of the Intergovernmental Panel on Climate Change. Cambridge University Press, Cambridge, United Kingdom and New York, NY, USA, p 1-32

Iverson LR, Prasad AM (1998) Predicting abundance of 80 tree species following climate change in the eastern United States. Ecol Monogr 68:465-485

Iverson LR, Prasad AM, Matthews SN, Peters M (2008) Estimating potential habitat for 134 eastern U.S. tree species under six climate scenarios. Ecol Manag 254:390-406

Jia M, Liu D, Song K, Wang Z, Ren C (2012) Mapping biomes of Australia based on the Holdridge Life Zone Model. Intl Conf Comp Vision Remote Sens IEEE 2012:362-365

Jain AK (2010) Data clustering: 50 years beyond K-means. Pattern Recog Lett 31:651-666

Johnson KL, Wickersham L, Neville T et al. (2011) Habitat use at multiple scales by pinyon-juniper birds on Department of Defense lands: landscape scale. Natural Heritage New Mexico Publication 10-GTR-360, Albuquerque NM, p 49

Jung M, Reichstein M, Ciais P, Seneviratne SI, Sheffield J, Bonan G, Chen J, Cescatti A, de Jeu RAM, Dolman AJ, Eugster W, Gerten D, Gianelle D, Gobron N, Goulden ML, Heinke J, Kimball J, Law BE, Montagnani J, Mu Q, Mueller B, Oleson K, Papale D, Richardson A, Roupsard O, Running S, Tomelleri E, Viovy N, Weber U, Williams C, Wood E, Zaehle S, Zhang K (2010) Recent decline in the global land evapotranspiration trend due to limited moisture supply. Nat 467:951-954

Kaye MW, Woodhouse CA, Jackson JT (2010) Persistence and expansion of ponderosa pine woodlands in the west-central Great Plains during the past two centuries. J Biogeog 37(9):1668-1683

Kelly AE, Goulden ML (2008) Rapid shifts in plant distribution with recent climate change. Proc Nat Acad Sci 105:11823-11826

Keys Jr J, Carpenter C, Hooks S, Koenig F, McNab WH, Russell W, Smith ML (1995) Ecological units of the eastern United States First Approximation (CD-ROM). U.S. Department of Agriculture, Forest Service. GIS coverage in ARCINFO format, selected imagery, and map unit tables, Atlanta, GA

Klos RJ, Wang GG, Bauerle WL, Rieck JR (2009) Drought impact on forest growth and mortality in the southeast USA: an analysis using Forest Health and Monitoring data. Ecol Appl 19:669-708

Kruskal WH, Wallis WA (1952) Use of ranks in one-criterion variance analysis. J Am Stat Assoc 47(260):583-621

Loarie SR, Duffy PB, Hamilton H, Asner GP, Field CB, Ackerly DD (2009) The velocity of climate change. Nature 462:1052-1055 
Loeb SC, Winters EA (2013) Indiana bat summer maternity distribution: effects of current and future climates. Ecol Evol 3:103-114

Lovett GM, Canham CD, Arthur MA, Weathers KC, Fitzhugh RD (2006) Forest ecosystem responses to exotic pests and pathogens in eastern North America. BioSci 56(5):395-405

Luce CH, Vose JM, Pederson N, Campbell J, Millar C, Kormos P, Woods R (2016) Contributing factors for drought in United States forest ecosystems under projected future climates and their uncertainty. Ecol Manag 380:299-308

Lugo AE, Brown SL, Dodson R, Smith TS, Shugart HH (1999) Special Paper: The Holdridge life zones of the conterminous United States in relation to ecosystem mapping. J Biogeog 26:1025-1038

Malanson G, Butler DR, Fagre DB, Walsh SJ, Tomback DF, Daniels LD, Resler LM, Smith WK, Weiss DJ, Peterson DL, Bunn AG, Hiemstra CA, Liptzin D, Bourgerson PS, Shen Z, Millar CI (2007) Alpine treeline of western North America: linking organism-to-landscape dynamics. Phys Geog 28:378-396

Maurer EP, Brekke L, Pruitt T, Duffy PB (2007) Fine-resolution climate change projections enhance regional climate change impact studies. Eos Trans Am Geophys Union 88(47):504. https://doi. org/10.1029/2007EO470006

McFarland TM, Mathewson HA, Groce JE, Morrison ML, Wilkins RN (2013) A range-wide survey of the endangered black-capped vireo in Texas. Southeast Nat 12:41-60

McNulty SP, Caldwell P, Doyle T, Johnsen K et al. (2013) Forests and climate change in the southeast USA. In: Ingram K, Dow K, Carter L, Anderson J eds. 2013. Climate of the southeast United States: variability, change, impacts, and vulnerability. Island Press, Washington, DC, p 165-189

McKenney DW, Pedlar JH, Hutchinson MF, Lawrence K, Campbell K (2007) Potential impacts of climate change on the distribution of North American trees. BioSci 57:939-948

McKenney DW, Pedlar JH, Rood RB, Price D (2011) Revisiting projected shifts in the climate envelopes of North American trees using updated general circulation models. Glob Change Biol 17:2720-2730

Meehl GA, Covey C, Delworth T, Latif M, McAvaney B, Mitchell JFB, Stouffer RI, Taylor KE (2007) The WCRP CMIP3 multimodel dataset: A new era in climate change research. Bull Am Meteor Soc 88:1383-1394

Memmott J, Craze PG, Waser NM, Price MV (2007) Global warming and the disruption of plant pollinator interactions. Ecol Lett 10:710-717

Menzel A, Sparks TH, Estrella N, Koch E, Assa A, Ahas R, AlmKubler K, Bissolli P, Braskvaska O, Briede A, Chmielewski F, Crepinsek Z, Curnel Y, Dahl A, Defila C, Donnelly A, Filella Y, Jatczak K, Mage F, Mestre A, Nordli O, Penuelas J, Pirinen P, Remisova V, Scheifinger H, Striz M, Susnik A, Van Vliet AJH, Wielgolaski F, Zach S, Zust A (2006) European phenological response to climate change matches the warming pattern. Glob Change Biol 12:1969-1976

Menzel MA, Menzel JM, Carter TC, Ford WM, Edwards JW (2001) Review of the forest habitat relationships of the Indiana bat (Myotis sodalis). U.S. Department of Agriculture, Forest Service, Northeastern Research Station. Report NE-284. Newtown Square, PA. $21 \mathrm{p}$

Millar CN, Stephenson N, Stephens S (2007) Climate change and forests of the future: managing in the face of uncertainty. Ecol Appl 17(8):2145-2151

Minnesota Department of Natural Resources and Minnesota Army National Guard. 2015. Minnesota Army National Guard, Camp Ripley Training Center and Arden Hills Army Training Site, 2014 Conservation Program Report, January 1-December 31, 2014. Compiled by Dietz NJ, Dirks BJ, Camp Ripley Series Report No. 24, Little Falls, MN. 208 pp.
Mohan JE, Cox RM, Iverson LR (2009) Composition and carbon dynamics of forests in northeastern North America in a future, warmer world. Can J Res 39:213-230

Moritz C, Agudo R (2013) The future of species under climate change: resilience or decline? Sci 341:504-508

Nakicenovic N, Alcamo J, Davis G, de Vries B, Fenhann J, Gaffin S, Gregory K, Grubler A, Jung TY, Kram T, La Rovere EL, Michaelis L, Mori S, Morita T, Pepper W, Pitcher H, Price L, Riahi K, Roehrl A, Rogner H, Sankovski A, Schlesinger M, Shukla P, Smith S, Swart R, van Rooijen S, Victor N, Dadi Z (2000) IPCC Special Report on Emissions Scenarios. Cambridge University Press, Cambridge, United Kingdom and New York, NY, USA, p 599

Notz D, Stroeve J (2016) Observed Arctic sea-ice loss directly follows anthropogenic $\mathrm{CO}_{2}$ emission. Sci 354(6313):747-750

Nowacki GJ, Abrams MD (2008) The demise of fire and "mesophication" of forests in the eastern United States. BioSci 58(2):123-138

Nowacki GJ, Abrams MD (2015) Is climate an important driver of post-European vegetation change in the Eastern United States? Glob Change Biol 21:314-334

Odom RH, Ford WM (2020) Developing species-age cohorts from forest inventory and analysis data to parameterize a forest landscape model. For Res. (in review)

Olson DM, Dinerstein E, Wikramanayake ED, Burgess ND, Powell GVN, Underwood EC, D' amico JA, Itoua I, Stand HE, Morrison JC, Loucks CJ, Allnutt TF, Ricketts TH, Kura Y, Lamoreux JF, Wettengel WW, Hedao P, Kassem KR (2001) Terrestrial ecoregions of the world: a new map of life on earth: a new global map of terrestrial ecoregions provides an innovative tool for conserving biodiversity. BioSci 51:933-938

Omernik JM, Griffith GE (2014) Ecoregions of the conterminous United States: evolution of a hierarchical spatial framework. Enviro Manag 54(6):1249-1266

Overpeck JT, Bartleinz PJ, Webb T (1991) Potential magnitude of future vegetation change in eastern North America: comparisons with the past. Sci 254(5032):692-695

Parmesan C, Yohe G (2003) A globally coherent fingerprint of climate change impacts across natural systems. Nat 421:37-42

Peery MZ, Gutiérrez RJ, Kirby R, LeDee OE, LaHaye W (2012) Climate change and spotted owls: potentially contrasting responses in the Southwestern United States. Glob Change Biol $18: 865-880$

Pierce DW, Barnett TP, Santer BD, Gleckler PJ (2009) Selecting global climate models for regional climate change studies. Proc Nat Acad Sci 106:8441-8446

Pielke Sr. RA, Adegoke JO, Chase TN, Marshall $\mathrm{CH}$, Matsui T, Niyogi D (2007) A new paradigm for assessing the role of agriculture in the climate system and in climate change. Agricul Meteor 142(2-4):234-254

Post E, Forchhammer MC, Bret-Harte MS, Callaghan TV, Christensen TR, Elberling B, Fox AD, Gilg O, Hik DS, Høye TT, Ims RA, Jeppsesn E, Klein DR, Madson J, McGuire AD, Rysgaard S, Schindler DE, Stirling I, Tamstorf MP, Nicholas NJC, van der Wal R, Welker J, Wookey PA, Schmidt NM, Aastrup P (2009) Ecological dynamics across the Arctic associated with recent climate change. Sci 325:1355-1358

Potter C, Li S, Huang S, Crabtree RL (2012) Analysis of sapling density regeneration in Yellowstone National Park with hyperspectral remote sensing data. Remote Sens. Environ 121:61-68

Prasad AM, Iverson LR, Matthews S, Peters M (2007) A climate change atlas for 134 forest tree species of the eastern United States [database]. Northern Research Station, USDA Forest Service, Delaware, $\mathrm{OH}$, http://www.nrs.fs.fed.us/atlas/tree

Pucko C, Beckage B, Perkins T, Keeton WS (2011) Species shifts in response to climate change: Individual or shared responses? J Torre Bot Soc 138:156-176 
Radeloff VC, Mladenoff DJ, He HS, Boyce MS (1999) Forest landscape change in the northwestern Wisconsin Pine Barrens from pre-European settlement to the present. Can J Res 29:1649-1659

Ralston J, Kirchmann JJ (2013) Predicted range shifts in North American boreal forest birds and the effect of climate change on genetic diversity in blackpoll warblers (Setophaga striata). Conserv Genet 14:453-555

Rehfeldt GE, Crookston NL, Warwell MV, Evans JS (2006) Empirical analyses of plant-climate relationships for the western United States. Int J Plant Sci 167:1123-1150

Rodenhouse NL, Matthews SN, McFarland KP, Lambert JD, Iverson LR, Prasad A, Sillett TS, Holmes RT (2008) Potential effects of climate change on birds of the Northeast. Mitig Adap Strat Glob Change 13(5-6):517-540

Rodenhouse NL, Christenson LM, Parry D, Green LE (2009) Climate change effects on native fauna of northeastern forests. Can J Res 39:249-263

Rogers TR, Russel FL (2014) Historical patterns of oak population expansion in the Chautauqua Hills, Kansas. J Biogeog 41:2105-2114

Seager R, Ting M, Held I, Kushnir Y, Lu J, Vecchi G, Huang H, Harnik N, Leetmaa A, Lau N, Lil C, Veleze J, Naik N (2007) Model projections of an imminent transition to a more arid climate in southwestern North America. Sci 316:1181

Seneviratne SI, Luthi D, Litschi M, Schar C (2006) Land-atmosphere coupling and climate change in Europe. Nat 443:205-209

Silvis A, Perry RW, Ford WM (2016) Relationships of three species of white-nose syndrome-impacted bats to forest condition and management. U.S. Forest Service Southern Research Station General Technical Report. SRS-214, Ashville, NC, p 57

Sisneros R, Huang J, Ostrouchov G, Hoffman F (2011) Visualizing life zone boundary sensitivities across climate models and temporal spans. Proced Comp Sci 4(2011):1582-1591

Snell RS, Cowling SA (2015) Consideration of dispersal processes and northern refugia can improve our understanding of past plant migration rates in North America. J Biogeogr 42:1677-1688

Vadeboncoeur MA, Hamburg SP, Cogbill CV, Sugimura WY (2012) A comparison of presettlement and modern forest composition in central New Hampshire. Can J Res 42:190-202
Van Mantgem PJ, Stephenson NL (2007) Apparent climatically induced increase of tree mortality rates in a temperate forest. Ecol Lett 10:909-916

Walther GR, Post E, Convey P, Menzel A, Parmesan C, Beebee TJ, Fromentin JM, Hoegh-Guldberg O, Bairlein F (2002) Ecological responses to recent climate change. Nature 416:389-395

Washington WM, Weatherly JM, Meehl GA, Semtner AJ, Bettge TW, Craig AP, Strand WG, Arblaster J, Wayland VB, James R, Zhang Y (2000) Parallel Climate Model (PCM) control and transient simulations. Clim Dynam 16:755-774

Weiss JL, Overpeck JT (2005) Is the Sonoran Desert losing its cool? Glob Change Biol 11:2065-2077

Williams AP, Allen CD, Macalad AK, Griffin D, Woodhouse CA, Meko DM, Swetnam TW, Rauscher SA, Seager R, Grissino-Mayer HD, Dean JD, Cook ER, Gangodagamage C, Cai M, McDowell NG (2012) Temperature as a potent driver of regional forest drought stress and tree mortality. Nat Clim Change 3:292-297

Williams JW, Shuman B, Bartlein PJ (2009) Rapid responses of the prairie-forest ecotone to early Holocene aridity in mid-continental North America. Glob Planet Change 66:195-207

Wood EM, Pidgeon AM, Gratton C, Wilder TT (2011) Effects of oak barrens habitat management for Karner blue butterfly (Lycaeides samuelis) on the avian community. Biol Cons 144:3117-3126

Woodall CW, Oswalt CM, Westfall JA, Perry CH, Nelson MD, Finley AO (2009) An indicator of tree migration in forests of the eastern United States. Ecol Manag 257:1434-1444

Woodall CW, Oswalt CM, Westfall JA, Perry CH, Nelson MD, Finley AO (2010) Selecting tree species for testing climate change migration hypotheses using forest inventory data. Ecol Manag 259(2010):778-785

Woolfenden GE, Fitzpatrick JW (1984) The Florida scrub-jay: demography of a cooperative-breeding bird. Princeton University Press, Princeton, NJ

Zar JH (2010) Biostatistical analysis, 5th edition. Prentice Hall, Upper Saddle River, NJ

Zhu K, Woodall C, Clark J (2012) Failure to migrate: lack of tree range expansion in response to climate change. Glob Change Biol 18:1042-1052 